ARH-LD-149 A

In formal. Report

ATLANTIC RICHFIELD HANFORD COMPANY

QUARTERLY REPORT

PROCESS TECHNOLOGY AND PROCESS DEVELOPMINII'

APRIL 1976 THROUGH JUNE 1976

Research and Engineering Division

August 1976

Atlantic Richfield Hanford Company

Richland, Washington 99352

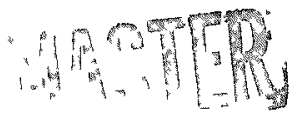




\section{DISCLAIMER}

This report was prepared as an account of work sponsored by an agency of the United States Government. Neither the United States Government nor any agency Thereof, nor any of their employees, makes any warranty, express or implied, or assumes any legal liability or responsibility for the accuracy, completeness, or usefulness of any information, apparatus, product, or process disclosed, or represents that its use would not infringe privately owned rights. Reference herein to any specific commercial product, process, or service by trade name, trademark, manufacturer, or otherwise does not necessarily constitute or imply its endorsement, recommendation, or favoring by the United States Government or any agency thereof. The views and opinions of authors expressed herein do not necessarily state or reflect those of the United States Government or any agency thereof. 


\section{DISCLAIMER}

Portions of this document may be illegible in electronic image products. Images are produced from the best available original document. 
TABLE OF CONTENTS

$\underline{\text { Page }}$

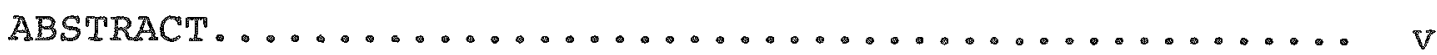

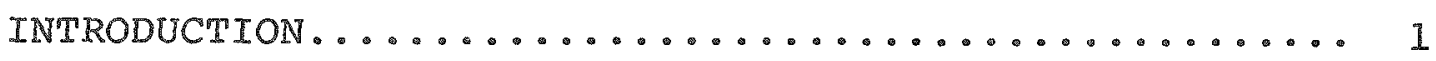

FUEL CYCLE RESEARCH AND DEVELOPMENT

COMMERCIAI WASTE MANAGEMENT.................. 2

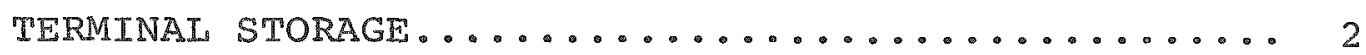

Documentation of Geological studies on

Columbia River Flood Basalts ät Hanford....... 2

SUPPORTING STUDIES - RESEARCH AND DEVELOPMENT..... 3

Sealed Storage Cask Demonstration............ 3

SPECIAL MATERIALS PRODUCTION

SEPARATIONS, PRODUCTION, AND SCRAP RECOVERY......... 11

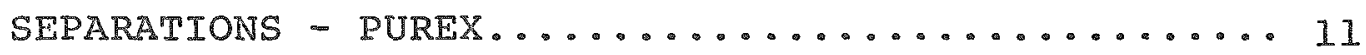

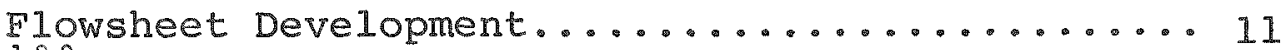

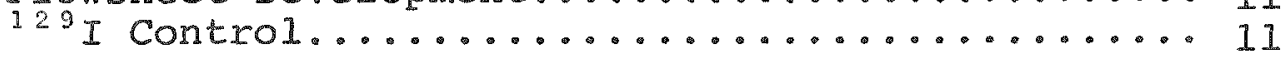

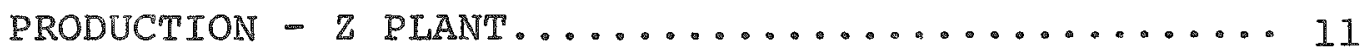

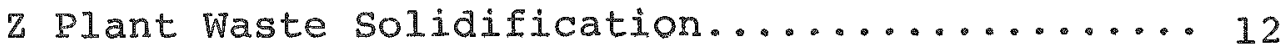

study of Plutonium Oxide

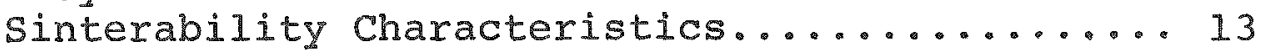

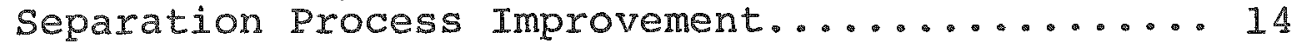

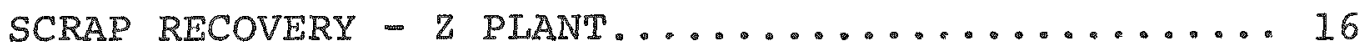

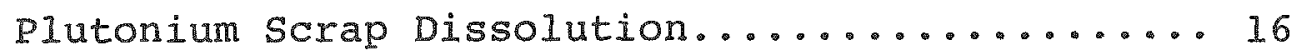

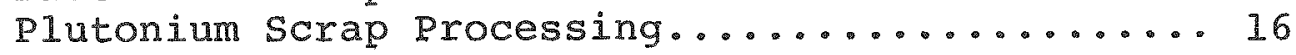

CURRENT WASTE MANAGEMENT - DEFENSE.............. 19

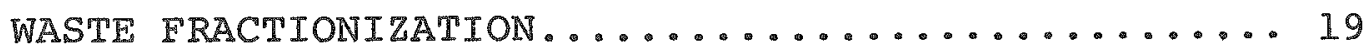

B Plant Extraction and Purification........... 19

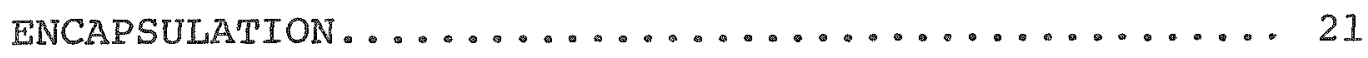


TABLE OF CONTENTS (continued)

Page

Instrumentation and Equipment Support......... 21

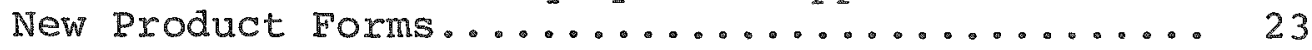

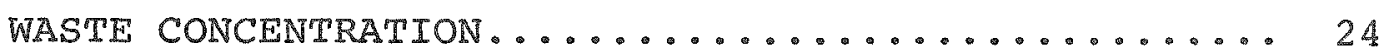

Interstitial Iiquor Removal............... 24

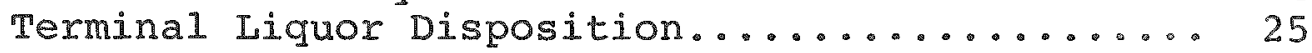

Salt Cake and sludge Characterization.......... 28

Redox Organic Waste Disposal................ 29

TANK FARM SURVEILIANCE AND MAINTENANCE......... 30

LONG-TERM MANAGEMENT OF DEFENSE WASTE AT HANFORD..... 33

STORAGE SYSTEM INTEGRITY-AND ENGINEERED

IMPROVEMENTS ............................ 34

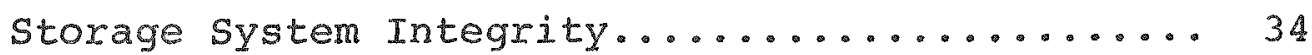

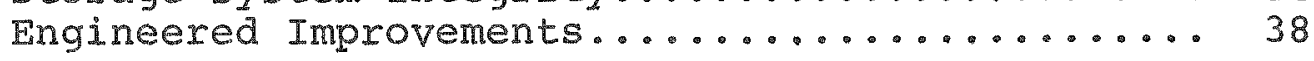

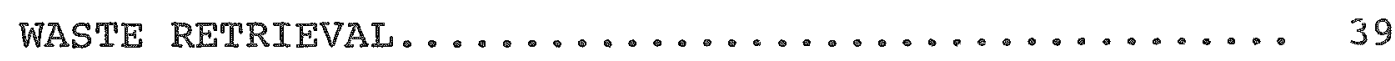

Concept and Equipment Development............ 40

Engineering Studies and Conceptual Design...... 42

IMMOBILIZATION AND STORAGE................ 43

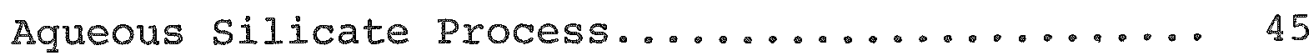

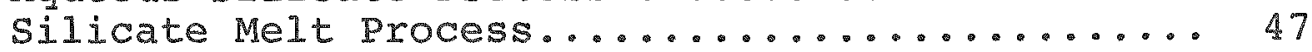

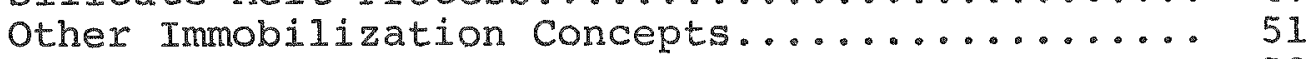

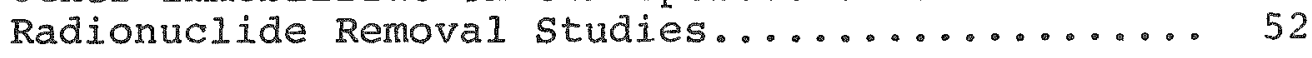

LONG-TERM MANAGEMENT OF CONTAMINATED SOILS

AND SEDIMENTS.............................. 59

CONTAMINATED SEDIMENT CONTROL................ 59

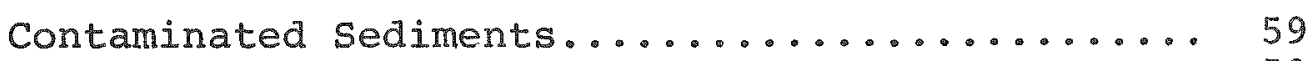

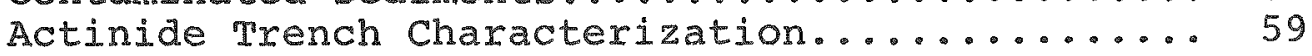

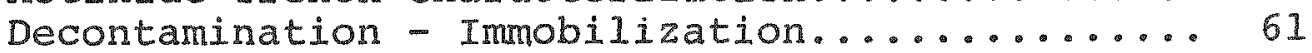

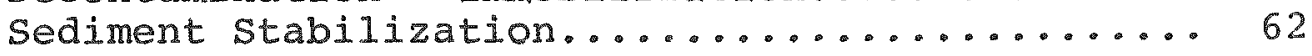

ENVIRONMENTAL IMPACT TECHNOLOGY................. 64

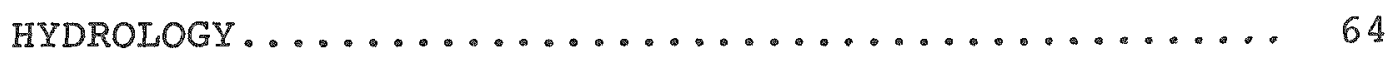


TABLE OF CONTENTS (continued)

Page

Groundwater Hydrology..................... 64

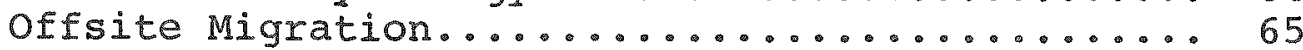

Radionuclide Migration in Groundwater.........66 67

Long-Term Groundwater Management............ 68

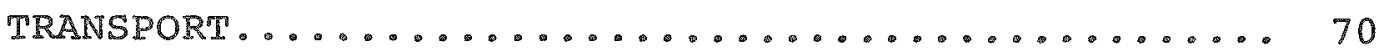

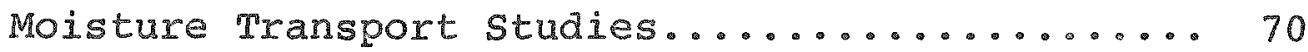

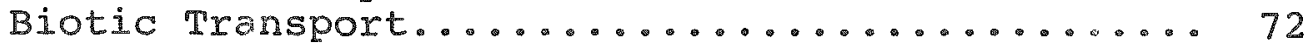

SEISMOLOGY AND GEOLOGY .................. 76

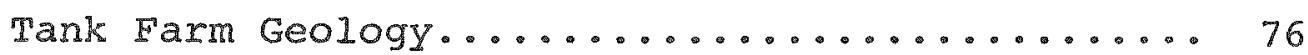

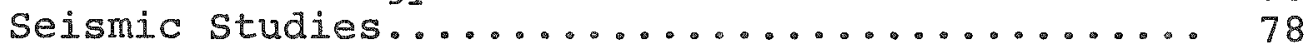

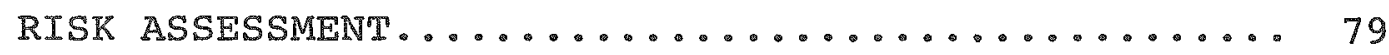

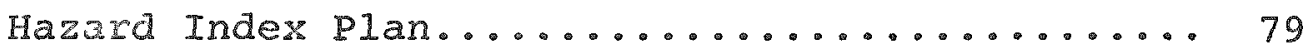

ANALYTICAI METHODS IECHNOLOGY DEVELOPMENT.......... 81

ANALYTICAL COMPUTER SYSTEMS................. 81

Subcritical Assembly for Low-Level

Fissile Analysis...................... 81

ANALYTICAL INSTRUMENTATION DEVELOPMENT ......... 82

Radiation Analysis Systems Development........ 82

Field Instrument Development.............. 84

ANALYTICAL METHODS DEVELOPMENT.............. 86

Analytical Development for Waste Management.... 86

Actinide Analytical Program.............. 87

ENVIRONMENTAL CONTROL TECHNOLOGY

MANAGEMENT OF SURPLUS FACILITIES AND EQUIPMENT....... 90

DISPOSITION METHODS RESEARCH AND DEVELOPMENT...... 90

Contaminated Equipment Volume Reduction........ 90

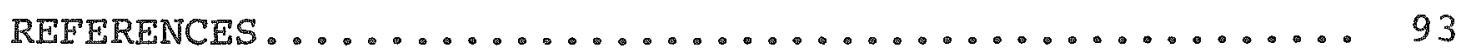

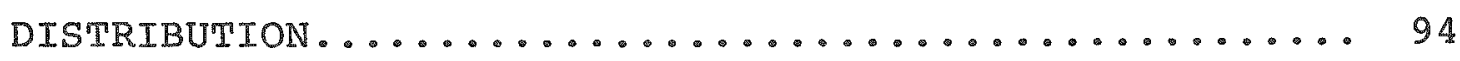




\section{ABSTRACT}

This quarterly report is the first in a series intended to provide information on research and engineering activities being performed to improve the processing of irradialed reactor fuels, the production of plutonium, and the management of resultant chemical wastes. The work reportol here was performed during the period Aprit through orune $i 976$. 


\section{ATIANTIC RICHETELD HANFORD COMPANY \\ QUARTERLY REPORT \\ PROCESS TECHNOLOGY AND PROCESS DEVELOPMENT}

\section{INTRODUCIION}

This report describes the scientific investigations and engineering application programs being sponsorct by the Energy Research and Development Administration (ERDA) under the direction of the Research and Engineering Division of the Atlantic Richfield Hanford Company (ARHCO).

This report presents summaries of technical progress. Brief statements of objective and prior work introduce individual portions of the report and appear in a type style different from that used to describe progress during the report period. The ERDA Division of Environmental Control Technology sponsors the mission entitled "Management of Surplus Facilities and Equipment:" other missions are sponsored by the Division of Nuclear Fuel Cycle and Production.

Previous periodical reports covering segments of this report's subject material were published as ARH-ST-110 A through D, ARH-ST-132 A through C, ARH-ST-128 A and B, ARH-ST-139, and ARH-LD-111 A through E. 


\section{FUEI CYCLE RESEARCH AND DEVELOPMENT}

\section{COMMERCIAL WASTE MANAGEMENT}

The overall objective of the Commercial Wasto Managemont mission is to develop and demonstrate the necessary technology and capability to safely maintain custody of commorial radioactive wastes so that they are not a threat to man and his environment now or in the future. The Commercial waste Management program covers a broad spectrum of radioactive wastes generated by facilities such as fuel fabrication plant . fuel reprocessing plants, and nuclear power reactors. It indudes such processcs as waste treatment, packaging, shipping, and interim and final storage.

TERMINAL STORAGE

Documentation of Geological studies on Columbia River Flood Basalts at Hanford - R. A. Deju

In 1968 the Atlantic Richfield Hanford Company injtiated studies to determine the feasibility of establishing a Einal storage facility for Hanford radioctive defense waste in caverns constructed within deep columbia River Flood basalts underlying the Hanford facilities. Included were geologic studies, to characterize the basalts and to understand theix relative stratigraphic positions, and hydrologic tests within the basalts and interbeds. Work was suspended in 1972, prior to the completion of data interpretation and the preparation of a final report. Early in 1976 ERDA initiated a national program designed to determine the feasibility of deep geologic storage caverns for commercial wastes at a number of locations in this the united states. The office of Waste Isolation, union Carbide Corporation, was assigned program management responsibilities, and they requested $\mathrm{ARHCO}$ to complete the interpretation and documentation of the early studies, inasmuch as the information may be valuable to 
current efforts to qualify the Columbia River Flood basalts for storage of commercial wastes.

During the report period work proceeded in the preparation of a report documenting the prior preliminary studies made to characterize the Columbia River Plateau Flood Basalt beneath the Hanford site. The report will contain eight sections summarizing the geologic, hydrologic, and engineering studies conducted to date and will be applicable to future studies of the feasibility of geologic storage oi wastes in Hanford basalt. The preliminary report will be completed by the end of september 1976 and submitted to the office of Waste Isolation, Union Carbide Corporation, for their review and issuance.

\section{SUPPORTIRG STUDIES - RESEARCH AND DEVELOPMENT}

Sealed Storage Cask Demonstration - D. C. Nelson, Program Manager

The Federal Government is required to assume permanent custody of all high-level radioactive waste within ten years of its generation by the commercial nuclear industry. Final waste storage sites and methods are under development by the Energy Research and Development Administration (ERDA). In the event that these final storage facilities are not available when waste deliveries begin, above-ground storage in a Retrievable surface storage Facility (RSSF) may be required to provide interim storage until final storage facilities are established. Atlantic Richfield Hanford Company has studied various interim storage concepts and is currently conducting engineering and demonstration programs to verify the feasibility of the sealed storage Cask Concept (SSCC) - concreteshielded steel casks placed outdoors and cooled by natural air circulation - as an interim storage concept. After 
completion of design verification in fiscal year 1977, a demonstration unit containing radioactive waste will be put in service in FY 1978 .

\section{Conceptual Design - J. R. LaRiviere}

Atlantic Richfield Hanford Company and Kaiser Engineers

(KE) have completed conceptual design studies for an RSSF based on the SSCC. This information has been documented in a conceptual system design description, readily available to serve as a basis for the final facility design should it be needed.

The conceptual design studies for an RSSF have been completed by $\mathrm{ARHCO}$ and $\mathrm{KE}$. The final report documenting this work was issued during the report period (ARH-LD-140, June 1976. Atlantic Richfield Hanford Company and Kaiser Engineers, "Retrievable surface storage Facility, Conceptual System Design Description").

\section{Conceptual Design Support Studies - J. M. Davis,}

J. R. LaRiviere, E. L. Moore

A demonstration unit (Figure 1 ) has been built and activities are being conducted to evaluate the integrity and feasibility of the SSCC. Important phases of this program are: (1) verification of heat transfer and radiation shielding calculations through tests with a sealed storage cask (SSC) demonstration unit equipped with an electric heater to simulate decay heat from the waste, (2) evaluation of the structural integrity of the storage cask, (3) evaluation of canister decontamination techniques as a means of establishing acceptable contamination levels for the outer surfaces of waste-filled canisters received by the RSSF, (4) investigation of surveillance methods to assure waste 


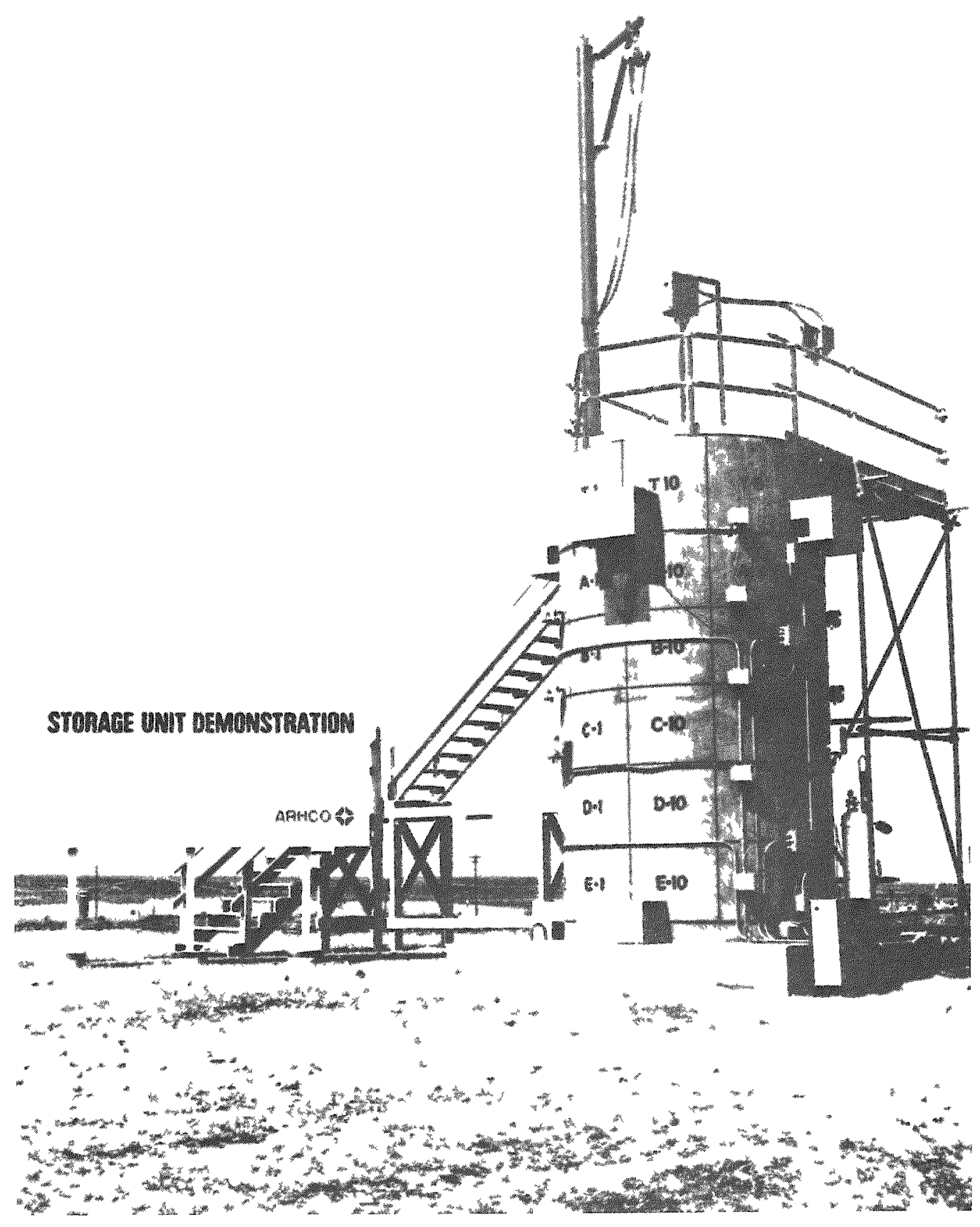

FIGURE 1

SEALED STORAGE CASR DEMONSTRATICN LNIT

AT HANFORD 
containment during storage, (5) evaluation of canister and cask handing methods, and (6) fabrication of an SsC to be loaded with radioactive waste to demonstrate the feasibility of the concept. Phases 1 through 4 are currently in progress while phases 5 and 6 have not yet been initiated.

Design Verification. Very little progress was made in continuing the heat transfer design verification testing on the SSC demonstration unit. In April, the electrical heater burned out and the Hanford Atomic Metal Trades Council (HAMTC) strike, which started a few days later, prevented repairs. Temperatures of the concrete shield and cask that have been observed are lower than calculated temperatures. Figures 2 and 3 summarize comparisons of observed and predicted temperatures.

Battelle-Northwest completed its comparison radiation shielding data, obtained using ${ }^{60} \mathrm{Co}$ and ${ }^{252} \mathrm{Cf}$ sources, with calculated dose rates for the outside of the SSC radiation shield. Inconsistencies in the results have led to further evaluations to determine if there are errors in the calculated dose rates or the test data.

Structural Evaluation. A technical report was issued by BNW covering the computer-based relative structural analysis of the four closure concepts being considered for the SSC: (1) a multi-plate closure, (2) a full-penetration circumferential butt-weld closure, (3) a threaded plug and seal weld closure, and (4) a corner weld closure. Based only on structural analysis BNW recommended the full-penetration circumferential butt-weld closure as the best closure method. A draft ARHCO report was completed that summarizes all the various studies performed to select a final closure concept. The draft is currently being reviewed and the results of the report will be discussed in the next quarterly report of this series. 


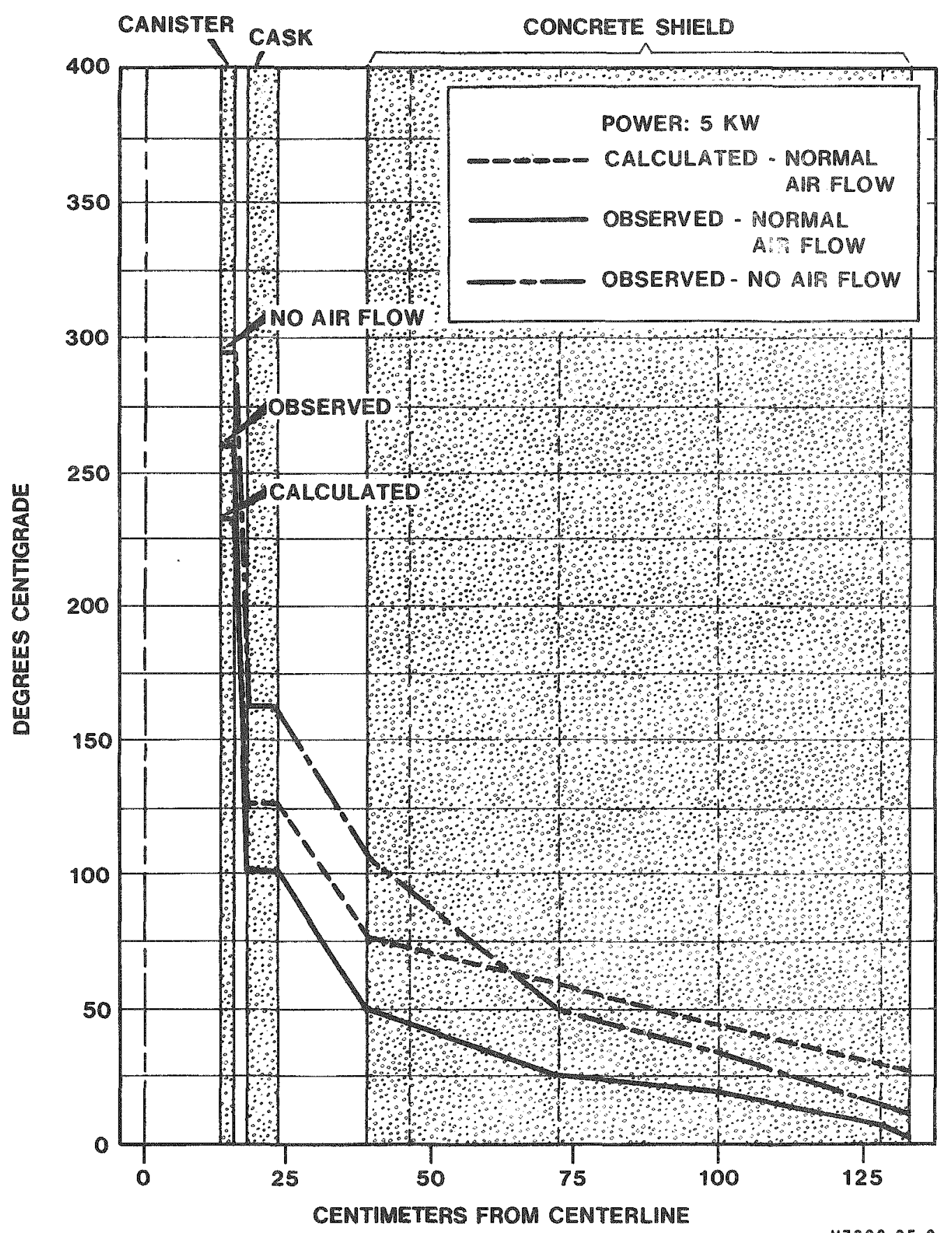

V7606-25.2

FIGURE 2

COMPARISON OF OBSERVED TEMPERATURE AVERAGES WITH PREDICTED AVERAGES IN THE SEALED STORAGE CASR DEMONSTRATION AT 5 KILOWATTS 


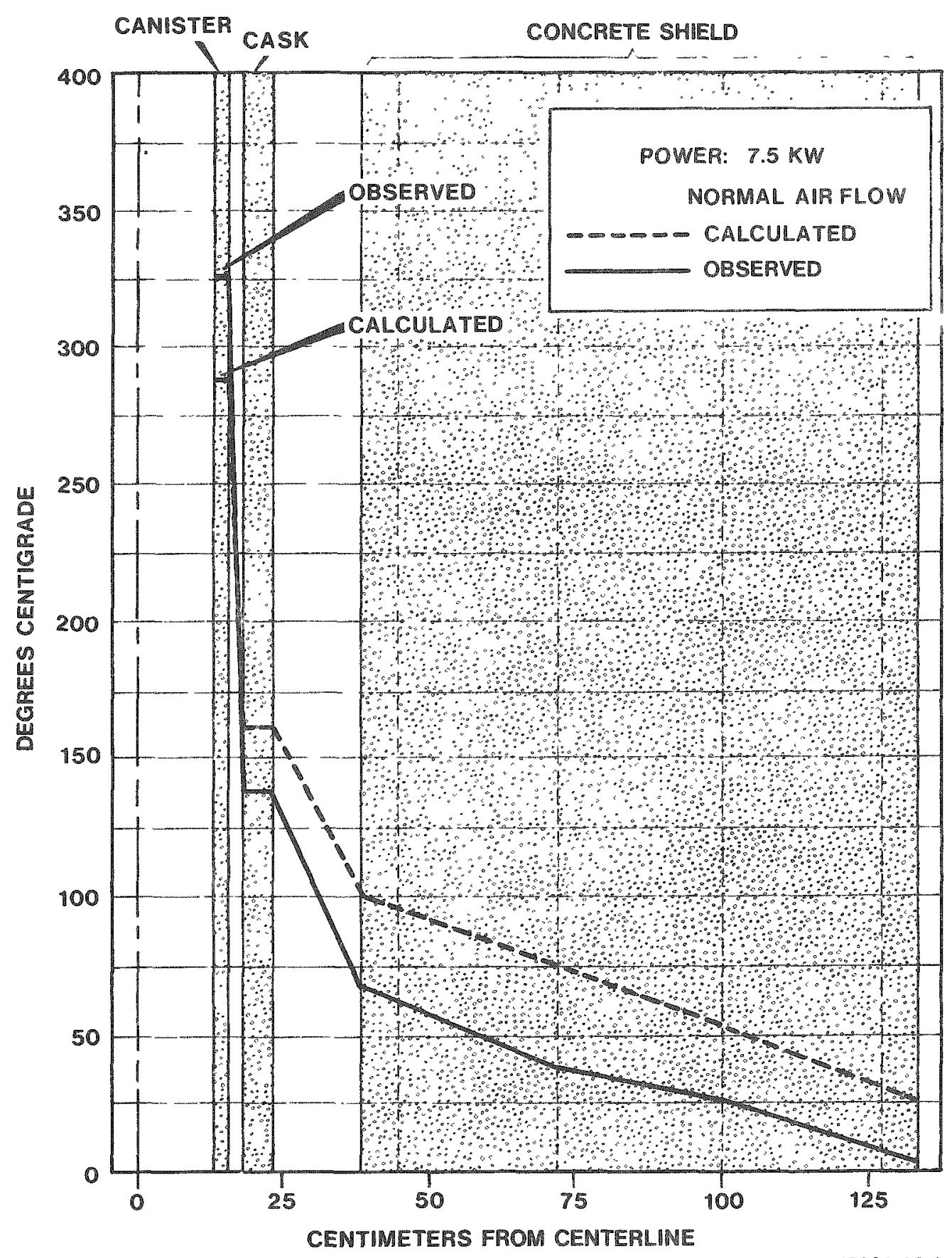

$\vee 7606.25 .1$

\section{FIGURE 3}

COMPARISON OF OBSERVED TEMPERATURE AVERAGES WITH PREDICTED AVERAGES IN THE SEALED STORAGE CASK DEMONSTRATION AT 7.5 KILOWATTS 
The storage cask structural analysis studies were continued with a more quantitative thermal stress analysis of the SSC. Thermal data from the demonstration unit were compared with the output of the ANSYs computer program to validate the accuracy of the program. A modified computer program will allow a quantitative structural analysis of the storage unit under blocked-air-flow conditions.

Decontamination Evaluation. Battelle-Pacific Northwest Laboratories completed its study of the effectiveness of steam and water sprays in decontaminating waste solidification Engineering Prototype (WSEP) canisters, and issued a summary report. A 40-minute treatment with only steam proved to be as effective as 140 minutes of exposure to both steam and water sprays, achieving decontamination factors ranging from 139 to 950 .

Tests to be conducted in a mini water basin will evaluate the relationship between the WSEP canister-surface contamination and the water activity level. The mini water basin is now in operation in a hot cell, and the testing with a contaminated WSEP canister has begun. No results are available.

Storage-Area Surveillance. Hanford Engineering Development Laboratory (HEDL) continued work on the design, fabrication, and testing of Geiger-Muller nuclear radiation detectors for surveillance of individual SSC integrity. The goal of this activity is to develop a reliable design for a surveillance radiation detector for the SSCC. The detectors should function unattended for long periods of time and should provide suitable signals to alert personnel to increases in detected radioactivity caused by a breach in an individual SSC within the facility. 
A prototype detector assembly was fabricated using the developed design concepts. The detector consists of a G-M type sensor coupled to a count rate meter. A direct-current voltage level proportional to the count rate serves as the detector output. This concept permits a central data station to rapidly scan a large array of detectors. The elecuronic circuitry for each detector, mounted on a printed circuit board, includes a miniature high-voltage source for the $G-M$ tube sensor. Thus, only one 12-volt power source must be supplied to each detector. The weatherproof assembly is designed to be inserted into an opening provided in the top of the storage unit, where it can be well shielded so as to minimize the background radiation in which it operates. An evaluation of the detector operation has been completed, and the results will be transmitted to ARHCO bY HEDL.

Work on the design, fabrication, and testing of solidstate radiation detector systems for use in SSC surveillance, as discussed above for the G-M detector systems, was completed by BEN-TRONICS Company, Kennewick, Washington.

A detection system was designed and fabricated. Six semiconductor devices were tested for their affinity to nuclear radiation detection. Tests were conducted to determine count rate versus source distance $\left(10 \mu \mathrm{Ci}{ }^{137} \mathrm{Cs}\right)$. count rate versus temperature, and count rate versus voltage across diode. The diode leakage current was measured as a function of temperature.

The four small diodes were not satisfactory as radiation detectors. This was attributed to the small junction area these devices possess. The two large diodes and a reference diode showed good characteristics at room temperature. At higher temperatures all the diodes showed poor characteristics, and operating temperatures up to $170^{\circ} \mathrm{F}$ are expected in the air flow through the annulus to cool the stored waste. No further work with the solid-state radiation detector systems is therefore planned at this time. 


\section{SEPARATIONS - PUREX}

The objectives of this program are to pxovide an updated Purex Flowsheet for the upcoming startup of the Puxex plant with development of technology for control of ${ }^{129}$ I during continuing reprocessing operations.

Flowsheet Development - D. W. Jeppson

Modification of the Pures Plant, changes in fuel to be processed, and requirements regulating the release of radioactive materials to the environment have resulted in a need to update the Purex Flowsheet. A rough draft of the updated flowsheet was completed and distributed for comments.

129 I Control - D. M. Strachan

Identification of the various pathways of ${ }^{129} \mathrm{I}$ in the Purex Plant is necessary in order to develop a plan to reduce emissions to the lowest practicable level. Initial experiments in this activity indicated that not all of the iodine is vaporized from the fuel dissolver solutions. During decladding only 50 percent of the iodine vaporizes. Less than 90 percent of the iodine contained in the dissolved fuel vaporizes from the $\mathrm{HNO}_{3}-\mathrm{Al}\left(\mathrm{NO}_{3}\right)_{3}$ dissolver solution.

\section{PRODUCTION - Z PLANT}

The objectives of this program are to improve throughput capacity, provide alternate products, improve operating efficiency, minimize the salt waste produced from recovery, and meet customer specifications for product quality anc product forms. 
2 Plant Waste Solidification ${ }^{12}$ D. A. Reynolds,

$A R H-L D-149$ A

M. J. Schliebe

The goal of this activity is to develop a concentrating and drying process for converting Plutonium Reclamation Facility (PRF) aqueous salt waste to a solid suitable for retrievable transuranic storage.

Prior work indicates that the evaporator will give an overall plutonium decontamination factor of approximacely $10 "$ " which exceeds the minimum design requirements. Work on the evaporator has been completed.

Initial data from the drum arior indicate that a solids production rate of $300 \mathrm{~g} / \mathrm{hr} / \mathrm{m}^{2}$ can be expected with moisture content of 12 to 17 percent. The three most important varjables in the production rate are drum speed, steam pressure, and percent solids in the feed. Drum speed is the most important vaxjable. Steam pressure and percent solids have less effect on the production rate.

During this quarter most work was directed at problems with corrosion of materials of construction.

Drum dxier runs were also made to evaluate the effect of acid digester waste from the Hanford Engineering Development Laboratory (IIEDL) prototype unit. A mixture of HEDI waste and $\mathrm{Z}$ Plant waste rapidly scaled the process equipment. Straight HEDL acid waste rapidly corroded the stainless steel lines and tanks. Neutralized HEDL waste was satisfactorily processed.

Work will be continued on evaluating the effect of different sodium and aluminum concentrations on drum drier operation. High aluminum coupled with a low sodium concentration was shown to lead to drier operating problems. 
Study of Plutonium oxide Sinterability Characteristics -

A. I. Dressen

Failure of Fast Flux Test Facility fuel-grade plutonium dioxide batches to meet the reactor developmenc technology specification for sinterability to 90 percent of theoretical density results in costly reprocessing and delays in shipping schedules. The objective of this activity is co develop the technology needed to consistently produce sinteruble puoz. The activity involves identifying powder charach istics which determine $\mathrm{PuO}_{2}$ sinterability and defining operating parameters to control these characteristics.

The characteristics of $\mathrm{PuO}_{2}$ from one production run were examined. Sintered densities increased one to three percent upon aging for one week although all samples initially sintered to greater than 90 percent of theoretical density. This aging phenomenon has been observed previously in powders of poor sinterability. Stoichiometry of the $\mathrm{PuO}_{2}$ was confirmed by measurement of the lattice parameters. The powders consisted of two types of agglomerates: small clusters of randomly oriented platelets and larger rosettes consisting of columnar growth radiating from a core which appeared similar to the small clusters.

Further examination of powder characteristics will be conducted during the next report period to define relationships between these and sinterability. In addition a benchscale model for semi-continuous $\mathrm{PuO}_{2}$ production will be utilized to select and define the operating parameters of feed adjustment, precipitation, and calcination which have important effects on powder characteristics and sinterability. 
Separation Process Improvement - I. E. Fort, M. J. KIem

\section{Solvent Extraction}

The SEPHI computer program has been altered for developing a mathematical model of the PRF solvent extraction process.

The standard plutonium(IV) flowsheet was documented using the results of the SEPHIS program. A statistical design of stream flowrates and concentrations was completed and a response equation was developed for predicting extraction and stripping column plutonium losses. Also, the effect of changing the 20 volume percent tributylphosphate (TBP) extract concentration to 18 and 22 percent was determined.

The SEPHIS program was altered for plutonium(IV) nitrate and nitric distribution into a solution of 20 volume percent tributylphosphate (TBP) in trichlorobenzene (TCB). The computer results showed that, under conditions identical to the TBP - $\mathrm{CCl}_{4}$ standard flowsheet, extraction column losses doubled and stripping column losses decreased by a factor of ten.

The extraction column losses could be reduced to the normal level by increasing the nitrate salt concentration of the solvent extraction feed by 15 percent or switching to the proposed alternative flowsheet. The alternative flowsheet was shown to reduce the quantity of high salt waste discharged and its extractable plutonium content by a factor of ten.

Future plans call for modeling and documenting the plutonium - uranium partitioning flowsheet for the TBP - CCI4 system. Work will continue on evaluating alternative diluents as comprehensive equilibrium data become available. 
Waste Treatment Columns

The purpose of this activity is to evaluate potential changes in the continuous waste Treatment Facility equipment and flowsheet for improved solvent extraction recovery of amexicium and plutonim. New extraction columns and process solvents will be tested.

An improved interface controller was installed on the pilot extraction column for smoothing the flow af organic to the downstream columns. A hold-down plate was installed in the top portion of the same column to prevent movement of the Kynar (Pennwalt Corporation) packing during the pulsing action. Test runs were started using synthetic highsalt waste (EIF) as the feed. The feed contained natural cerium(III) as a substitute for americium(III). Aqueousorganic phase mixing efficiency was evaluated for columns containing $2.5 \mathrm{~cm}$ Kynar plastic Intalox saddles and $1.6 \mathrm{~cm}$ stainless steel pall ring packing. Laboratory problems in analyzing for cerium have prevented quantitative evaluation of the test runs.

The SEPHIS computer program was altered for the distribution of plutonium(IV) nitrate, americium(III) nitrate and nitric acid into the dibutylbutylphosphonate (DBBP) $\mathrm{CCl}_{4}$ organic. The computer results showed that under conditions identical to plant operation virtually all the plutonium and only 41 percent of the americium are extracted. The addition of two extra extraction stages (five total) gave a one percent increase in americum extraction. Reducing the aqueous to organic flow ratio (Aq/O) from 3.5 to 2.0 increased americum extraction to 69 percent. The computer results confirm the findings of an earlier engineering analysis and show that increasing the organic flow rate is more beneficial than the addition of extra extraction stages. 
Laboratory column tests will be made to verify the higher organic flowrates. Tests will also continue for improving column efficiencies by varying pulse conditions, using other types of colum packing material, using different sieve and nozzle plates, and using new process solvents.

SCRAP RECOVERY - 2 PLANT

Plutonium Scrap Dissolution - C. E. White

Plutonium-bearing scrap is generated as a result of purification, fabrication and handing operations. The objective of this activity is to determine optimum dissolution and/or leaching conditions compatible with Plutonium Reclamation Facility (PRF) operations for receiving this plutonium.

A prototype plutonium scrap dissolver was fabricated and tested under laboratory conditions. The tests used sand and ash material as feed. A production rate of two liters of solids per hour was achieved. Testing has shown the dissolver solution flowrate is limited by the vertical movement of particles in the settling zone of the dissolver.

capacity testing using synthetic materials will continue to determine maximum flowrates for different types of scrap seed.

Plutonium Scrap Processing - W. W. Schulz

Bidentate Estraction

Unlike commonly-used monodentate extractants $(e \cdot g \cdot$. tributylphosphonate [TBP] and DBBP), bidentate organophosphorus reagents such as dihexyl-N,N-diethylcarbamylmethylene phosphonate (DHDECMP) extract both $\mathrm{Am}^{3+}$ and $\mathrm{Pu}{ }^{4+}$ strongly from concentrated $\mathrm{HNO}_{3}$ solutions. The objective of this activity is to develop a DHDECMP solvent extraction process 
to recover americium and plutonium directly from the acidic (.2 $2 \mathrm{HNO}_{3}$ ) waste stream produced in the Hanford PRF operations, therby avoiding the pH adjustment step required by the present DBBP extraction scheme. A secondary objective is to develop plutonium, amexicium, and HNos distribution data for purified 30 and 40 percent DHDECMP extractants and various aqueous phase compositions.

Two different bidentate flowsheets are being developed for possible use in the PRF. One, which employs a 40 rolume percent DHDECMP-TCB extractant, is designed to reduce soluble americium and plutonium values in acid waste solution to or below $10 \mathrm{nCi} / \mathrm{gram}$ levels. A second flowsheet, which employs a 30 volume percent DHDECMP-TCB extractant, is intended for application with the same flows and equipment used in the present DBBP Elowsheet. Extensive mixer-settler runs simulated both extraction and partition column conditions and were executed with 40 percent DHDECMP-TCB solvent purified either by ethylene glycol washing or by hydrolysis with $6 \mathrm{M}$ $\mathrm{HCl}$ at $60^{\circ} \mathrm{C}$. With the 40 percent DHDECMP flowsheet, americium (III) was satisfactorily partitioned from co-extracted plutonium(IV) by operating with four mixer-settler stages at $50^{\circ} \mathrm{C}$ and $0.1 \mathrm{MNO}_{3}$ as the partitioning agent. Under these conditions 80 - 90 percent of the americium accompanied by only 4 - 5 percent of the plutonium reported to the aqueous product stream。

The computer program SOLVEX, recently developed at the Savannah River Laboratory, was successfully used to calculate steady state performance of the partition (S1) column of a conceptual DHDECMP flowsheet. Using tabulated americium, plutonium and $\mathrm{HNO}_{3}$ distribution data obtained with purified 40 percent DHDECMP-TTCB extractant, the calculated amounts of americium and plutonium in the aqueous product (SIP) stream 
produced under typical partition column conditions $\left(50^{\circ} \mathrm{C}\right.$, 4 stages, aqueous: organic flows $=1 / 2$ ) were 98.6 and 6.3 percent, respectively. In an actual mixer-settler test under these conditions, 95 and 4.3 percent, respectively, of the americium and plutonium reported to the SIP stream.

Efforts during the next report period will focus on completion of additional mixer-settle flowsheet tests and on determining the capacity of Amberlyst A-26 (Rohm and Haas Company) resin for removing acidic impurities from ethrlene glycol washed 30 percent DHDECMP-TCB solvent. 


\section{WASTE FRACTIONIZATION}

The waste fractionization program is designta to improve strontium recovery and purification process perecmance. Increased process efficiency will decrease stronim waste losses and cut processing costs at B Plant.

B Plant Extraction and Purification - D. G. Bouse, J. S. Buckingham, S. S. Koegler

\section{Strontium Solvent Extraction}

Solvent extraction laboratory work has been performed to provide eslifibrium data for the sePHIS computer model. Previously, equilibrium batch contact data were generated for aqueous strontium and sodium solutions and an organic in normal parafin hydrocarbon diluent.

Equilibrium batch contacts were also made using a synthetic purex acidified sludge (PAS) mixture and different chelate blends.

During this report period, batch equilibrium contacts were made in the stripping region of $i \mathrm{H} 0$ to 3 . Distribution coefficients were measured for strontium, calcium, and sodium. This program is now complete.

\section{Solvent Extraction Modeling}

The purpose of the solvent extraction model is to provide an accuxate and convenient means for $B$ Plant solvent extraction flowsheet modification and as an engineer training tool. During the previous report period, the IA (extraction) column and the is (sodium scrub) column were successfully modeled. Comparisons of predicted and actual plant data were very good. 
During this report period, the SEPHIS computer program was extended to the $1 B$ (strontium partition) Column and the 1C (rare earth partition) column. Calculated strontium waste losses were lower than actually experienced, probably due to solubility considerations. Calcium and other cation stripping corresponded well with plant data. Work on the solvent extraction computer model is essentially complete.

\title{
Strontium Purification
}

\author{
Laboratory tests were conducted to improve the irst \\ strike of the Srsou purification process. Neither increas- \\ ing the $p H$ nor increasing the $\mathrm{SO}_{4}{ }^{2-}$ concentration with $\mathrm{H}_{2} \mathrm{SO}_{4}$ \\ measurably decreased strontium losses. Since improvements to \\ the sulfate purification process itself were not feasible, a \\ process was developed to reclaim the strontium from the first \\ sulfate strike waste. A lead carrier precipitation process \\ was developed which recovered at least 90 percent of the \\ strontium, with good calcium and magnesium decontamination, \\ from synthetic first-strike waste. \\ During this report period, a series of cold initial \\ screening tests were conducted to evaluate process variables \\ which might affect the metathesis step of the sulfate purifi- \\ cation process. It is considered most likely that strontium \\ lost from this process step is finely divided solids, so a \\ series of settling time experiments was made. These experi- \\ ments indicated that solution composition and solids/1iquid \\ ratio had a much greater effect on settling time than did \\ temperature and digest time. The same process variables will \\ next be tested for their effect on the size and number of \\ particles remaining in the metathesis supernate following \\ centrifugation.
}




\section{Removal of Cesium by Ion Exchange}

During previous purex current acid waste (CAW) campaigns. cesium was removed from Purex CAW by precipitating cesium phosphotungstate in a mildy acidic solution. The process was not entirely satisfactory because of high cesium losses and the high cost of phosphotungstatic acid.

Scouting runs have been started testing the ability of various ion exchangers to remove cesium from Purex CAW, $B$ Plant strontium solvent-extraction feed, B Plant scrontium solvent-extraction raffinate, and neutralized $\mathbb{B}$ Flant strontium solvent-extraction raffinate. The work was only recently started, so no data are available at this time.

The equilibrium distribution efficients constants for cesium will be measured as a function of acidity or alkalinity for synthetic waste streams with several ion exchange resins.

\section{ENCAPSULATION}

Operating problems with certain equipment in the waste Encapsulation and storage Facility (WESF) has created a need for development of new equipment so encapsulation production goals can be met. The purpose of this program is to provide the process technology necessary to solve equipment and process problems existing in the WESF.

\section{Instrumentation and Equipment Support - J. D. Moore} Tilt-pour and Pan Dry Cesium Equipment

A flowsheet and equipment for achieving desired WESF rates for solidification and encapsulation of Cscl are being developed in tests with full-scale equipment. Two processes have been selected for parallel development. The tilt-pour process utilizes an induction-heated vessel in which CsCI solution is dried and melted. The molten salt is then poured 
into the storage capsules for solidification and capping. In the second process, a stirred, steam-heated pan drier is used to evaporate the CsCl to a dry, free-flowing salt which is discharged into storage capsules which are vibrated for salt compaction.

Equipment prototypes have been designed and fabricated along with full-scale mock-ups which will be used for concurrent remote mechanical testing with manipulators.

During the report period, the tilt-pour and pan-drier prototypes were installed in the development laboratory and testing with nonradioactive CsCl was started. successful demonstration of transfer of molten salt from the tilt-pour melter to storage capsules was achieved in each of the three tests attempted. The need for redesign of the pan-arier stirrer was discovered in four tests with CsCl. In each test, the stirrer stalled when the solution was evaporated to a wet salt. Modification of the stirrer is in progress.

The tilt-pour mock-up was installed in a test station which was built for simulated remote operation. Recent tests with manipulators have shown that the tilt-pour capsule holding mechanism must be modified for ease of capsule loading and removal in the hot cell.

\section{Capsule Decontamination}

Development work is proceeding to provide an alternative in-cell method for decontaminating production capsules at the Waste Encapsulation and Storage Facility. Electropolishing equipment compatible with in-cell operation has been designed and built. Cold testing of this equipment has shown an acceptable capsule surface removal profile. A cell mock-up has been constructed, and the equipment is currently being tested in this mock-up for remote handing with manipulators. 
Hot Pressing strontium Fluoride

An alternative process for encapsulating $\mathrm{SrF}_{2}$ is being developed. Hot pressing of $\mathrm{SrF}_{2}$ powder has been attempted. Hot pressing at $700^{\circ} \mathrm{C}$, and then heating the SrF 2 up to $1100^{\circ} \mathrm{C}$ without pressing, has been determined to be feasible. A slug two inches in diameter and nine inches long has been produced by this method, using cold strontium fluoride with typical WESF impurities. A small disc with a density 95 percent of theoretical has been prepared with this process.

Further work is required on equipment developaent and prototype testing to develop hardware which is compalible with the WESF.

New Product Forms - D. M. Strachan

There is a need to consider alternative product forms for cesium and strontium which eshibit more desirable longterm storage characteristics. Toward this end, cesium glasses have been developed, as well as a process for producing pollucite $\left(\mathrm{CsAlSi}_{2} \mathrm{O}_{6}\right)$ from CsCl and bentonite clay. These products have high cesium storage densities and low leach rates.

During the report period emphasis has been shifted to the alternatives to $\mathrm{SrF}_{2}$. Consideration has been given to several preparative routes to strontium orthosilicate $\left(\mathrm{Sr}_{2} \mathrm{SiO}_{4}\right)$. Strontium orthosilicate has the same strontium storage density as $\mathrm{SrF}_{2}$, and, although the exact water solubility is not known, it should be lower than the solubility of $\mathrm{SrF}_{2}$. Strontium orthosilicate also has the advantages of low corrosivity and high compatibility with future waste management concepts. 
WASTE CONCENTRATION - R. J. Thompson, Program Manager

The objective of this program is to transiorm liguid high-level waste into less mobile solids, and to safely isolate these solids from the biosphere for an extended time.

Interstitial Iiquor Removal - W. P. Metz

The objective of this activity is to develop and demonstrate methods for removing as much interstitial lignid from Hanford waste storage tanks as is technically and economically practicable and to immobilize the residual Iiquid.

A mathematical model has been developed which appears to adequately describe the liquid flow in salt cakes. Instrumented salt well facilities for Tanks 241-BY-107 and 241-S-111 were installed and tested. These facilities are to provide data to verify a model of interstitial liquid flow through salt cake. Two deep well jet pumps were received and modified for testing in the instrumented salt well facilities. The jet pump as standard salt well pumping equipment is recommended based on performance of the pumps and the production from the wells during the tests.

A preliminary evaluation of evaporation to reduce the amount of interstitial liquor was completed. The technique appeared to be beneficial particularly when applied to sludges. A process test was proposed to obtain drying data on both salt cakes and sludges. A salt cake liquid heel immobilization concept, the "capillary pump," was identified. The concept utilizes the high capillary forces of diatomaceous earth to immobilize the heel which is expected to remain after salt well pumping.

The testing of the prototype Moyno Pump (Moyno Pump Division, Robbins and Myers. Inc.) was completed. Driveshaft problems were encountered so that no further development work on this pump will be done. Installation of 
ventilation equipment for the in $3 i$ tu drying test was started but was hampered by work stoppage. Engineering studies and bench scale tests were initiated to model the fluid flow for the capillary pump concept.

Terminal Iiquor Disposition - W. E. Ogren

The objectives of this activity are ro devclop and demonstrate processes for converting terminal liquos lo acceptable solids for interim storage preferably $1 n$ existiny inderground waste storage tanks.

Alternative processes for achieving interim disposition of terminal liquors have been investigated in engineering laboratory, pilot plant and plant process tests. The seven alternatives originally proposed have been reduced to three:

- Interim storage of terminal liquors in doubleshe11 tanks.

- Partial neutralization treatment of terminal liquors to product salt cake for single-shell tank storage leaving reduced volume of terminal liquors for double-shel1 tank storage.

- Additional evaporation of terminal liquors in the evaporator-crystallizers, producing reduced volumes of salt cake and mother liquor requiring doubleshell tank storage (double-shell slurry process).

Predictive tools have been fashioned to aid in evaluation of the impact of the disposition alternatives. Definition of the waste chemistry by laboratory study has provided the basis for predictions.

Continued processing of waste liquids has produced salt cake and concentrated bottoms liquor approaching a composi- 
tion not suitable for further evaporation with a singleshell tankage system. Flowsheet control of the evaporatorcrystallizer will effectively meet the constraints imposed on evaporation by the single-shell tankage system. The information used in assembling the draft flowsheet document is based on plant operations experience, pilot-plant studies, laboratory studies, and engineering studies. Additional laboratory boildown studies have been undertaken to verify the concentration limits as well as provide indications of product properties and evaporator operating conditions. Large-scale pilot plant studies were performed on feeds similar to initial 242-A Evaporator-Crystallizer feedstooks.

The process test evaluation document for the partial neutralization test carried out in November and December was completed by the end of April. Construction of the partial neutralization prototype facility for 242-S EvaporatorCrystallizer was under way until the beginning of the HAMTC and construction-pipefitters strike. Construction is about 50 percent complete. Plans are being made for testing and evaluating the prototype after construction is completed. Functional Design Criteria for partial neutralization facilities at 242-A have been completed.

An information manual describing the prototype equipment and operation is being assembled. A study of fluid jets and fluid mixing for acid injection design is nearly complete. An improved acid injector will be designed and installed for the prototype testing.

A consolidated approach to routine application of partial neutralization, making it a simple subcase of standard evaporator operation, has been studied. A flowsheet document, presenting this approach as a simple control algorithm will be issued.

The double-she11 slurry process is being developed to 
further evaporate terminal liquors resulting from salt cake production in single-shell tanks. The product slurry is stored in double-shell tanks for an interim period awaiting final disposition. The double-shell slurry process, which produces a salt cake mixture of $\mathrm{NaNO}_{3}, \mathrm{NaNO}_{2}$, and $\mathrm{NaAlO}_{2}$ with supernatant mother liquors, offers additional volume reduction of wastes destined for double-shell tank storage.

Initial bench-scale studies indicate the process is feasible. Sodium aluminate does not precipitate promptly like $\mathrm{NaNO}_{3}, \mathrm{NaNO}_{2}, \mathrm{NaCO}_{3}$, and sodium phosphates. Postprecipitation of $\mathrm{NaAlO}_{2}$ in the slurry receiver tant will result in a layered salt cake. A draft proposal document for plant testing of the double-shell slurry process was issued for review. Laboratory studies of the double-she11 slurry piocess were outlined to achieve a targeted amount of boildown for two different feeds. Boildown ratio, temperature. pressure, and product characteristics will be reported.

The liquor resulting from the concentration of B Plant strontium recovery solvent extraction wastes contains soluble chelates of strontium, plutonium, and americium. Iaboratory boildown tests have been completed wherein one volume of actual high-strontium waste was blended with two volumes of synthetic terminal liquor of the composition expected to result from the processing of 242-T liquors. Volume reductions of 30 to 40 percent were made. The resulting solids were very fine and could not be separated by centrifuging, indicating very poor settling of solids in the slurry receiver tanks. While crystals could be seen in the filtered solids, these solids retained considerable mother liquor due to the small particle size. 
The boildown study results indicate that separate storage of the high strontium concentrate for at least interim periods is the preferred disposition method for several reasons: (1) the concentrate has a higher viscosity than does normal terminal liquor, which will slow the delivery rate of interstitial liquor to the salt well; (2) fine particles will reduce salt cake permeability and further reduce salt well pumping rates; (3) the fine particles have a higher potential for releasing retained liquor by ostwald ripening; and (4) the strontium, plutonium, and americium remain in the liquor phase, which results in both a potential increase in operating problems if the waste is processed over long periods, as well as producing larger volumes of arainable but nonpumpable liquors containing mobile strontium. plutonium, and americium in salt cakes.

Laboratory scouting studies are under way to determine if the addition of $\mathrm{Ca}(\mathrm{OH})_{2}$ or $\mathrm{Ca}\left(\mathrm{NO}_{3}\right)_{2}$ can displace the strontium and/or plutonium and americium from the chelate. other feasibility studies include partial oxidation, hydrolysis, or precipitation of the chelating agents.

Salt Cake and Sludge Characterization - G. K. Allen

The objective of this subtask is to obtain core samples of waste tank solids and to define chemical and physical properties of the solias stored in waste tanks as a function of depth or strata.

Prior to this report period, cold demonstration tests of the sampling system were performed to evaluate operating procedures and equipment and to allow the Hazards Review Team to observe the overall operations. Minor changes in the operating procedures were made as a result of these tests. During this report period, five samples were arilled from Tank 241-TX-116. Seventeen inches of solids were recovered from these core samples. Physical characterization 
of the core samples was completed. Due to the HAMTC strike, chemical analyses were not completed and no further core sampling was done.

one probe, which is part of the electrical resistance system that indicates tank liner contact, was steam sluiced into the tank, establishing electrical contact with the tank liner. The actual bottom detection system was not tested. The physical characterization procedures were completed during this report period. The glovebox for characterization work was partially installed, but further shielding is needed. The salt cake standard was developed and fully tested. Two sludge standards, a bismuth phosphate - uranium recovery sludge and a Purex - Redox sludge, are still being developed. The precision of the present analytical laboratory methods was documented; all physical measurements are within the required accuracy. Many of the chemical analysis procedures have not been fully tested on the salt cake and. therefore, accuracy has not been established.

\section{Redos Organic Waste Disposa1 - L. Q. Fong}

The objectives of this activity are to characterize the waste, define a disposal concept, install suitable equipment, and dispose of the organic wastes stored in Tanks 276-S-141 and $276-S-142$.

Wall thickness measurements to determine the integrity of Tanks 276-S-141 and 276-S-142 are completed and documented. The tank integrity is adequate to allow orderly disposal of the Redox organic waste. The following evidence substantiates that the tank walls are sound:

- Only one tank thickness measurement (0.286 inch) deviated below all the other measurements ranging from 0.327 to 0.363 inch. 
- Organic waste and radioactive contamination were not detected around the outside of the tanks.

- Routine surveillance of the tanks since 1967 shows no change in liquid level.

Characterization of the Redos organic waste in the two tanks is complete and documented. The analytical methods are included with the results of the chemical and radiochemical analyses. The radiochemical analysis indica-es the contamination level of the organic waste is low except for ${ }^{129} I$.

The waste in Tank 276-S-141 can be evaporated to dryness, but only 40 percent of Tank 276-S-142 can be evaporated. The proposed process of in situ evaporation before incineration is feasible but will not completely dispose of the Redox organic waste. The most direct method of disposing of Redors organic is to incinerate the waste.

Proposals to prepare a conceptual design and conduct limited pilot studies to incinerate the Redox organic waste were solicited and received from offsite consultants. The proposals were evaluated and recommendations were made to the Purchasing Department, but no bid will be awarded due to current budget constraints.

\section{TANK FARM SURVEILLANCE AND MAINTENANCE}

The objectives of this program are to improve existing waste tank surveillance methods and equipment and surveillance of waste transfer lines. New surveillance techniques and equipment are being developed where needed.

A contract was signed in April 1976 with the Boeing Company for the development of a prototype leak detection system. This system is to be installed on five tanks in the A tank farm complex and is to demonstrate that the 
theory of operation developed under a previous research contract can be put into practice in an operating tank farm environment. A similar system was previously installed and is being tested on Tank 102-AX. Descriptions of the applied techniques are being witheld pending filing of patent applications.

The contract's duration is for thirty weoks and is close to schedule in both time and cost. Assuming the development is successful, expansion into a larger system is desirable and could be implemented for approximately $\$ 50,000$ per tank. The aix-purged weight factor dip tubes tested in Tank 241-S-111 have proven accurate for determining interstitial liquid level but have the problem that they "salt-over" and do not always function properly. The steam and water flushing that was incorporated during the report period into the Tank 241-S-111 salt-we11 pumping procedure has proven effective but has the drawback of adding more liquid to the tank.

Development work is in progress for the use of a solid state electronics pressure transducer and readout system that will record liquid depth by pressure measurement. The system has been tested under pilot conditions and has shown satisfactory resistance to the "salt-over" problem and the caustic nature of the liquids involved. The system is scheduled to be incorporated into the Tank 241-S-111 saltwell system as soon as craftsmen are available to do the installation. A second method of measuring interstitial liquid level involves the use of a modified neutron probe. This is a modified version of a probe already in use with a prototype ready for testing in four months.

A clamp-on flow meter using an ultrasonic measuring technique has been successfully tested under a variety of conditions. Tests are in progress to demonstrate its 
usefulness in transfer-line surveillance and material accountability.

Installation of a prototype "in-place" gamma monitoring system is awaiting completion of equipment construction. The prototype system contains 45 stationary radiation detectors placed in nine dry wells around a tank which are automatically monitored by a minicomputer. The computer will perform a statistical analysis on data received and will provide an alarm when a problem exists. 


\section{LONG-TERM MANAGEMENT OF DEFENSE}

\section{WASTE AT HANFORD}

The overall objective of this mission is to develop, evaluate, and demonstrate the technology for the long-term management of the Hanford high-level waste which will remain upon completion of the current waste solidification program. This waste will consist of approximately 3,500 capsules of ${ }^{90} \mathrm{Sr}$ and ${ }^{137} \mathrm{Cs}$ stored in water basins and 6,000,000 cubic feet of material in underground tanks. Because these wastes will remain hazardous for hundreds to thousands of years, a long-term waste management program is needed to insure long-term isolation of the waste from man's environment.

The alternatives being considexed for Hanford high-level defense wastes are:

- To retrieve the waste, process it to an improved stabilized form, and store it retrievably in deep natural rock or other formations (geologic storage).

- To retrieve the waste, process it to an improved stabilized form, and store it in new retrievable surface storage facilities for an interim period, with eventual transfer to a final storage site.

- To continue storage of the wastes in existing tanks and capsules as is, or with improvements to the storage facilities to extend the period of safe storage.

The mission has been divided into three major tasks:

- Storage System Integrity and Engineered Improvements

- Waste Retrieval

- Waste Immobilization and storage. 
Each of these is discussed separately in the following sections. The program will extend at least into the mid$1980^{\circ} \mathrm{s}$.

\section{STORAGE SYSTEM INTEGRITY AND ENGINEERED IMPROVEMENTS -}

P. F. Mercier

$$
\begin{aligned}
& \text { The objectives of this program are: } \\
& \text { To develop a data base to permit the annul } \\
& \text { assessment of the safety of continued waste } \\
& \text { storage in the existing underground tanks. } \\
& \text { To identify, develop, and test engineered } \\
& \text { improvements that would extend the safe } \\
& \text { waste-storage period in the existing tanks. } \\
& \text { To analyze the safety and the effect on the } \\
& \text { biosphere of continued waste storage in the } \\
& \text { existing tanks. }
\end{aligned}
$$

There is a need for this program because high-level

waste will continue to be stored in the older single-shell tanks until a permanent storage mode is identified.

Although the presently solidified waste is immobile compared to the original liquid form, there is concern about the continued reliability of the tanks because of the potential hazard in the event of loss of containment. The first annul assessment of the safety of continued waste storage in the Hanford tanks is planned for publication at the beginning of FY 1978. Testing and selection of engineered improvements to the storage tanks are scheduled for completion in FY 1980. 


\section{Storage System Integrity}

The following activities are planned to providu a data base to assess the integrity of the waste storage tanks and to develop methods to periodically evaluate their integrity.

\section{Salt Cake Stability - G. A. Beitel}

The nitrates and nitrites which form the bulk of salt cake are energetically capable of reacting with any organic materials which may be present. Safe storage of high-level wastes such as salt cake requires that violent or uncontrolled exothermic reactions between the salt cake and any organic materials present be kinetically impossible.

Tests have shown no evidence of susceptibility to shockinitiated detonation or to combustion within the moisture nitrate organic mixture calculated to be present.

Additional testing of salt cake nitrates mixed with organic materials was given consideration during the report period because the tendency of exothermic reactions to accelerate to uncontrollable rates depends on a number of factors, the most important of which include the energy of the reaction and the pressure and overall heat-transfer characteristics of the system. While the energy content is fixed for a specific chemical composition, the heat transfer characteristics depend on the size and geometry of the systems. Completed combustion tests used one-gram samples at atmospheric pressure. The additional tests being considered will use larger, pressurized samples to allow more realistic extrapolation to those extreme storage conditions which may promote exothermic reactions. 
Containment Integrity $-\mathbb{F} \cdot R$. Vollert

The objective of this activity is to determine the integrity of the reinforced concrete tanks. The extended use of the waste-storage tanks will depend on how seriously elevated temperature, thermal cycling, and chemical solutions have affected the elastic properties of the concrete and the reinforcing steel.

Two laboratory programs have been developed by the Portland Cement Association Laboratories (PCAL) to investigate the effects of elevated temperatures and simulated waste on specimens of the kind of concrete used in Hanford tank construction. All specimens were manufactured with Hanford aggregate and the original $3000 \mathrm{psi}$ and $4500 \mathrm{psi}$ concrete formulations.

The two-year-1ong elevated-temperatures activity has been under way less than one year and definite results are not yet available. Specimens are 6 inches in diameter by 12 inches long and are exposed to temperatures of 250,350, and $450^{\circ} \mathrm{F}$. Tests are performed to determine the modulus of elasticity, Poisson's Ratio, compressive strength, and splitting tensile strength while the specimens are at test temperature.

The waste-chemicals investigation was continued by PCAL using 3-inch-wide by 3-inch-thick by 11-1/4-inch-1ong prisms made with the same concrete formulations used for the elevatedtemperatures specimens. Thirty different exposure conditions were used combining temperatures of 50,100, and $150^{\circ} \mathrm{C}$ and solution variables of $4 \mathrm{~N}, 7 \mathrm{~N}, 10 \mathrm{~N} \mathrm{Na}(\mathrm{OH})_{2}$ and $0 \underline{\mathrm{N}}$,

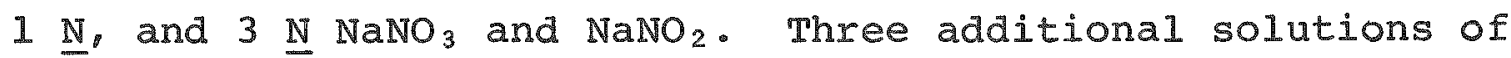
$\mathrm{Ca}(\mathrm{OH})_{2}$ at 50,100 , and $150^{\circ} \mathrm{C}$ served as the control exposures. Eighteen of the 120 specimens contained reinforcing steel. Tests were made to determine the change in length, weight, sonic measurements, and electrical potential measurements 
of the specimens containing reinforcing steel.

All testing was discontinued after six months of specimen exposure based on the usual failure criterion of 0.100 percent expansion. The length-change measurements showed that in all alkali solutions, the rates of expansion were progressively greater with increasing exposure temperature. In contrast, all prisms in the $\mathrm{Ca}(\mathrm{OH})_{2}$ solutions showed only minor expansions that were within the range encountered in normal moist curing.

The weight-change measurements were considesed an unreliable measure of durability because crystallized salt from the test solutions adhered to the specimens, more than offsetting any weight losses due to deterioration.

The sonic measurements were also considered to be less reliable indicators of deterioration than the length-change measurements, due in part to crack-filling (densification) through precipitation of salts from test solutions, which would tend to offset frequency drops due to crack development.

The results of electrical potential measurements, performed to reveal the condition of reinforcing steel embedded in the specimens, were considered inconclusive because severe cracking of the concrete had permitted solution to penetrate to the reinforcing steel. For this reason the specimens were broken open after 6 months of exposure and examined visually. No evidence of corrosion was observed for any specimen.

An analysis of concrete cores taken from the domes of in-service tanks was initiated. Fifteen cores originally removed by tank-farms operations personnel were shipped to PCAL. They will be tested to determine their compressive strength and elastic properties, and petrographic analysis of their microstructures will be performed. The data 
will be correlated with that from the elevated-temperature testing to establish criteria to be used in determining the conditions of the tank concrete.

New concrete test specimens for the waste-chemicals investigation will be developed in conjunction with PCAI during the next report period.

\section{Engineered Improvements - P. F. Mercier}

The objective of this activity is to identify, develop, and demonstrate methods and techniques that can extend the safe storage period of the solidified waste in the underground tanks. These engineered improvements are needed to assure containment of the solidified waste within a confined system regardiess of storage-tank integrity and natural phenomena. Double containment has been provided in the design of the newer tanks holding the terminal liquor and for the capsules holding ${ }^{90} \mathrm{Cs}$ and ${ }^{137} \mathrm{Sr}$. The criteria for engineered improvements also is to provide double containment for the solidified waste and to prevent collapse of a reinforced concrete tank dome because of seismic, external, or impact loading.

A technical literature search has been completed which indicates that soil stabilization methods developed over the past forty years may provide this double containment by making it possible to create an impervious barrier to radionuclide migration in the soil surrounding a waste-storage tank. Consulting companies specializing in the use of this technique have been contacted about the storage conditions at Hanford. A demonstration of the selected techniques is planned for FY's 1977 and 1978 .

Consultant assistance was sought during the report period to determine a feasible method to provide assurance that a tank dome will not collapse under the design earth load because of loss of reinforced concrete elasticity with time, or an increased earth load, or accidental impact on the earth cover by a falling aircraft or other missile. 
Further discussion with these consultants, and with those specializing in the use of soil-stabilization techniques, will take place during the next report period.

\section{Tank Safety Analysis - D. J. Brown}

The purpose of this activity is to determine the effects upon the biosphexe of continued storage of the solidified waste in the single-shell tanks. This analysis will determine the radiologic impact upon man resulting from the loss of containment through failure of the storage system.

A draft of the program plan was completed and reviewed. A wind-field computer model simulating the airborne suspension of waste material has been developed by the BattelleNorthwest Laboratories. This model is being modified and tested for the conditions in the storage-tank areas. Reactions between soil sediments and waste chemicals were under study. Laboratory techniques to determine radionuclide transport in partially saturated sediments are virtually nonexistent and consultant help is being planned.

\section{WASTE RETRIEVAL - I. E. Reep}

The objective of this program is to develop and demonstrate the technology necessary for retrieval of the waste material (salts, sludges, liquids, and accumulated debris) from the underground storage tanks. This technology will provide the Hanford High-Level Radioactive Waste Management Program with the option of removing the stored wastes to permit their conversion to a more acceptable product form. The waste retrieval program consists of the following five activities:

- Concept and equipment development

- Engineering studies and conceptual design 
- Engineering design

- Fabrication ana construction

- Prototype test operations.

Conceptual design of the proposed waste retrieval system will be completed in FY 1977, and fabrication of this system will begin near the end of FY 1978. Cold testing of major components of the waste retrieval system could take place in FY 1980, with hot testing and demonstration of this equipment beginning in FY 1982 .

Concept and Equipment Development - I. E. Reep

The objectives of this activity are:

- Identification of potential retrieval techniques.

- The definition of areas of the waste retrieval program which will require technology development and evaluation.

- Preliminary testing of the identified retrieval techniques to establish feasibility.

- Evaluation and reporting on engineering studies and designs performed in support of this activity.

The major portions of the concept development portion of this activity are complete. The major components for accomplishing the waste retrieval objective have been identified. They are the (1) prototype waste retrieval system, (2) prototype test facility and, (3) facilities for hot demonstration.

In the equipment development portion, potential cetrieval methods have been identified and their feasibility has been established in "bench scale" tests. Future work under this 
activity will be directed toward developing specialized retrieval tools and equipment. The major emphasis will be placed on the development of hydraulic retrieval devices, with secondary emphasis on mechanical and pneumatic retrieval tools and equipment.

\section{Equipment and Tool Development - N. M. Arnold}

The objective of this activity is to develor tools and equipment fox recovery and removal of wastes fron the underground tanks. Work is currently being focused on the development of hydraulic retrieval devices.

Two Scumbuster (Vaughan Company, Inc., Montesano, Washington) agitator pumps axe being evaluated for their capability to slurry salt cake in its own interstitial liguor and pump the resulting slurry out of the tank. This technique could also be used for the retrieval of sludge if the moisture content is sufficiently high. A hydraulic retrieval test loop has been installed for use with the larger, 100-horsepower pump, which has successfully slurried and pumped synthetic salt cake containing up to 70 weight percent included solids.

Work progressed on the design and fabrication of a mobile stand for use in testing the ability of a modified 60-horsepower scumbuster pump to remove solid radioactive wastes from the Hanford waste tanks with the addition of very little or no liquid to the tanks.

One objective of the test is to determine the pumping and flow characteristics of synthetic salt cake slurries as a function of the percentage of solids in the slurry. 
Engineering studies and Conceptual Design - I. E. Reep

This activity consists of:

- Engineering studies in problem areas requiring further definition, and

- Conceptual designs for the further development of concepts and equipment identified as feasible in the Concept and Equipment Development activity.

A number of engineering study reports have been received from consultants. These include an engineering study and cost estimate for a waste retrieval system; a design study of a salt cake retrieval system; a study evaluating the adaptability of standard mechanical, hydraulic, and pneumatic devices to salt cake and sludge retrieval at fanford: and a study of the high-level waste management technology development program. This information will provide a basis for conceptual designs of a prototype waste retrieval system, a prototype test facility, and facilities for hot demonstration.

Waste Retrieval System - H. A. Wallskog

The objective of this activity is to provide the conceptual design of a full-scale, completely integrated waste retrieval system having the capability of retrieving waste from any of the 75-foot-diameter Hanford waste-storage tanks.

The general approach and design concept for development of a prototype retrieval system is contained in the draft of "Concept for Retrieval of Hanford High-Level Waste" (DraftARH-LD-144) which was prepared during the report period. The necessary engineering design and subsystem integration studies will be performed under the contract to be established in July 1976 with the Programmed and Remote Systems Corporation St. Paul, Minnesota. 
The overall waste retrieval system concept, illustrated in a previous quarterly report, consists of a large mobile platform supporting th. major in-tank subs:stens as well as all waste handing and packaging, service and control func-

tions. (1) The principal element of the waste retrieval system concept is the articulated arm shown schematically in Figure 4. This hydraulically actuated mechanical arm will have the capability of positioning a variety of recovery and removal devices within any of the 75-foot-diameter Hanford waste storage tanks.

\section{Prototype Test Facility - N. M. Arnold}

The objective of this activity is the conceptual design of a facility for use in testing and demonstrating the capability of a complete waste retrieval system in a nonradioactive environment. Design of the cold test stand, a metal structure that would permit limited testing of retrieval system components, has been completed and is being held for future reference. The cold test stand will be constructed only if lengthy delays are expected in completing the prototype test facility.

Conceptual design of the prototype test facility, which is part of the Long-Term Waste Management Equipment Test Facility, was completed by Vitro Engineering during the report period.

\section{IMMOBILIZATION AND STORAGE - R. A. Watrous}

The objectives of this program are:

- Identification, development, and demonstration of technologies for converting high-level waste to an immobilized form satisfactory for long-term ox Einal storage. 


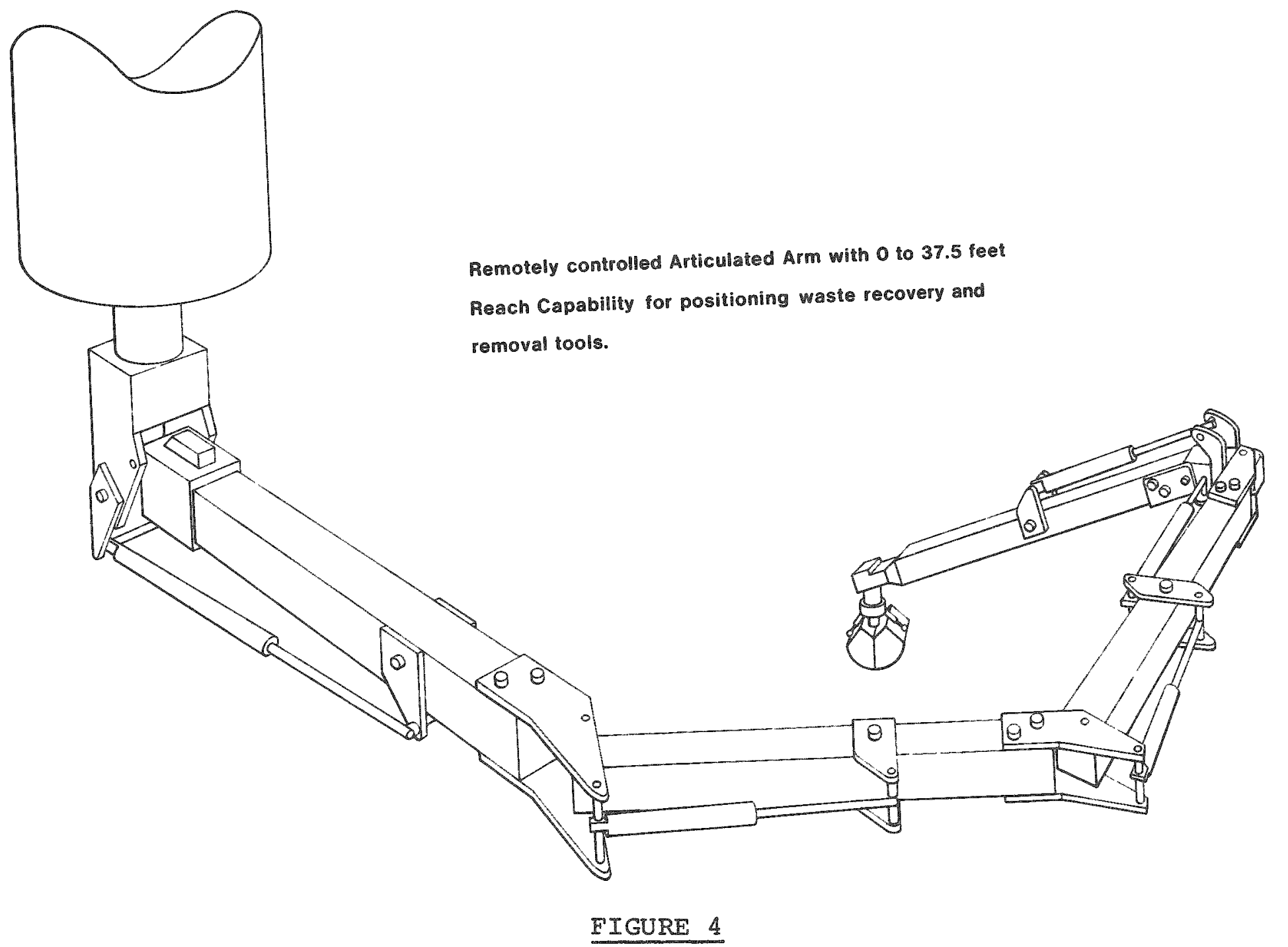

IN-TANK WASTE RETRIEVAL EQUIPMENT CONCEPT

IN-TANR WASTE RETRIEVAL EQUTPMENT CONCEPT 
- Evaluation of alternative engineered and final storage methods.

\section{Aqueous Silicate Process}

The conversion of fission product wastes to solid, insoluble products suitable for long-term or final storage is being investigated through the Aqueous Silicate process. This process utilizes reactions of clay with waste to form stable products. Basically, three processing options are available in the Aqueous silicate process, as duaribed in previous reports. During this report period develcpment was directed exclusively toward the high tempexature version clay calcination. In this process dry waste materials (such as salt cake) or other dehydrated wastes are reacted with clay at $600^{\circ}$ to $800^{\circ} \mathrm{C}$ to form water-and nitrate-free sodium aluminosilicate powders. These powders may then be incorporated with binders or sintered to form clay calcination products.

Leaching of Clay Calcination Products Made from Actual Salt Cake - M. J. Kupfer and C. H. Delegard

Leach rates were determined for clay calcination products prepared by fixation of salt cake from Tank 102-SX. Charges containing from 25 to 40 weight percent salt cake (the balance of the charge being kaolin) were reacted at $800^{\circ} \mathrm{C}$. The mixtures were then pressed $(20,000$ psi) and sintered at $1000^{\circ} \mathrm{C}$.

The product specimens were leached at $25^{\circ} \mathrm{C}$ using the International Atomic Energy Agency proposed leach method. The results (Figure 5) indicate leach rates based on ${ }^{137} \mathrm{Cs}$ are not significantly dependent on the salt cake content for products containing 25,30 , and 35 weight percent salt cake. The best leach rate was obtained for the 30 weight percent specimen. The specimen containing 40 weight percent salt cake leached at the highest rate $-1.5 \times 10^{-4} \mathrm{~g} / \mathrm{cm}^{2}$-day after 70 days. 


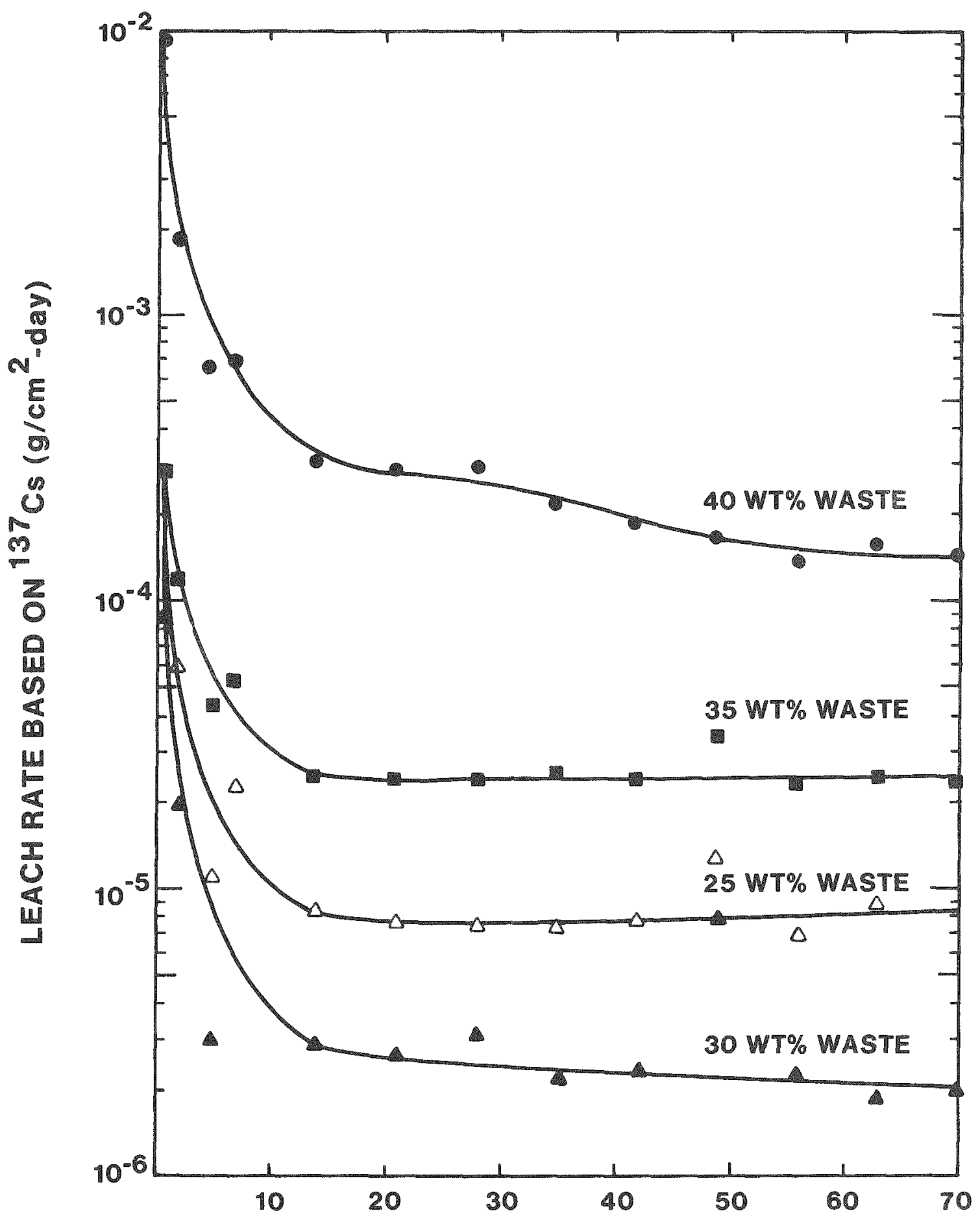

LEACH PERIOD, DAYS

V7608-10.1

FIGURE 5

LEACH RATES FOR SINTERED CLAY CALCINATION

PRODUCTS MADE WITH ACTUAL SALT CAKE 
During the next report period, application of clay sintering to fixation of actual sludge and terminal liquor samples will be demonstrated.

Silicate Melt Process - M. J. Kupfer, W. W. Schulz

The objectives of this activity are to develop and demonstrate processes for incorporation of fanford highlevel wastes into immobile silicate-based glass forms. Present laboratory-scale glass-making activitues are aimed at (a) development and demonstration of suitable processes for conversion of Hanford sludges and terminal lixuors to glasses, and (b) construction and operation of a small-scale (10 - $25 \mathrm{~kg}$ of glass per day) all-electric, continuous melter.

In previous work, both low melting $\left(\leq 1000^{\circ} \mathrm{C}\right)$ and high melting $\left(\geq 1000^{\circ}\right.$ C) glass formulations were developed for general sludge wastes and tested for durability and viscosity. Work during the current report period was aimed at investigating formulations for terminal liquor and sulfate-bearing sludges.

\section{Fixation of Terminal Liquor in Glass}

Scouting experiments to derive formulations for fixation of terminal liquor were initiated this quarter. Portions of solids resulting from evaporation of synthetic terminal liquor solution (Table I) were melted $\left(1000-1200^{\circ} \mathrm{C}\right)$ with various glass-forming ingredients. Table II sumarizes the compositions that produced the most desirable products based on appearance and leachability. The products in Table II were all homogeneous, clear, green glasses. Leach rates (after five days of leaching at $25^{\circ} \mathrm{C}$ ) were quite low $-7 \mathrm{x}$ $10^{-7}$ to $10^{-5} \mathrm{~g} / \mathrm{cm}^{2}$-day based on cesium. 


\section{TABLE I}

COMPOSITION OF SYNTHETIC TERMINAL IIQUOR SOLUTION

$\begin{array}{ll} & \frac{\mathrm{M}}{\mathrm{NaAlO}_{2}} \\ \mathrm{NaNO}_{2} & 2.0 \\ \mathrm{NaNO}_{3} & 2.5 \\ \mathrm{NaOH} & 2.0 \\ \mathrm{Na}_{2} \mathrm{CrO}_{4} a & 5.0 \\ \mathrm{Na}_{2} \mathrm{SO}_{4} & 0.3 \\ \mathrm{Na}_{2} \mathrm{CO}_{3} & 0.15 \\ \mathrm{Cs}_{2} \mathrm{CO}_{3} b & 0.1\end{array}$

$\alpha_{\text {The concentrations of chromate and sulfate used in }}$ the synthetic terminal liquor are three times those of actual liquor, (based on limited data obtained from only two samples). The concentrations of these components were selected so that a worst-case situation could be approximated in respect to causing second-phase problems. Typical actual terminal liquors could contain much less sulfate and chromate.

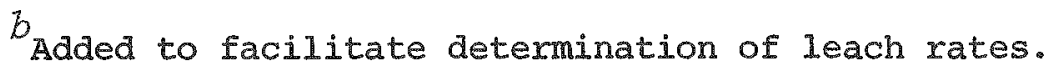


TABLE II

TERMINAI LIQUOR VITRIFICATION RESULTS

\begin{tabular}{|c|c|c|c|c|c|c|c|}
\hline \multirow{3}{*}{$\begin{array}{c}\text { Dehydrated } \\
\text { Terminal } \\
\text { Iiquor } \\
\end{array}$} & \multicolumn{4}{|c|}{ Composition, wt.\% } & \multirow[b]{3}{*}{$\begin{array}{l}\text { Temp. } \\
{ }^{\circ} \mathrm{C} \\
\end{array}$} & \multirow{2}{*}{\multicolumn{2}{|c|}{$\begin{array}{c}\text { Leach Rate. Based on } \mathrm{Cs} \\
\mathrm{g} / \mathrm{cm}^{2}-\mathrm{day} \\
\end{array}$}} \\
\hline & & & & & & & \\
\hline & $\mathrm{SiC}_{2}$ & $\mathrm{~B}_{2} \mathrm{O}_{3}$ & $\mathrm{TiO}_{2}$ & $\mathrm{Li}_{2} \mathrm{O}$ & & 24 hours & 120 hours \\
\hline 30 & 60 & 10 & - & - & 1200 & $1.1 \times 10^{-5}$ & $2.8 \times 10^{-6}$ \\
\hline 29 & 58 & 10 & - & 3 & 1100 & $1.0 \times 10^{-5}$ & $7.3 \times 10^{-7}$ \\
\hline 27 & 50 & 13 & 10 & - & 1100 & $9.8 \times 10^{-16}$ & $2.0 \times 10^{-6}$ \\
\hline 26 & 53 & 8 & 10 & 3 & 1100 & $5.0 \times 10^{-6}$ & $1.2 \times 10^{-6}$ \\
\hline
\end{tabular}

Workers at Savannah River Laboratory have noted that the addition of sulfate to glass formulations often results in formation of an undesirable water-soluble sulfate phase that is rich in cesium and strontium. (2) Although phase separation was no problem with the formulations shown in Table II, a soluble sulfate phase did indeed separate during melting of several other terminal liquor glass formulations.

In future work, the maximum concentrations of sulfate that can be incorporated into several glass formulations will be determined and techniques for preventing formation of the separate phase will be investigated. Volatility of cesium during the melting step will be determined.

\section{Fixation of Sulfate-Bearing Sludge in Glass}

Recent laboratory tests indicate that a limited amount of sulfate can be incorporated into glass formulations for fixation of Hanford sludge. As noted with terminal liquor glasses, a water-soluble sulfate phase that is rich in cesium and strontium segregates to the surface during melting.

Results showed that from 2.9 to 17 percent of the cesium and from 0.6 to 17 percent of the strontium separated from the melts when as little as 0.25 to 0.5 weight percent 
sulfate was present in glasses made from Redox sludge. Nearly all of the cesium and strontium separated out when melts contained 1.0 to 1.5 weight percent sulfate. The glass melts containing Purex sludge showed much less tendency to form separate phases than did those containing Redoss sludge. At least one weight percent sulfate in the glass was required to produce a water soluble cesium and strontium phase for purex glass formulations. (This is approximately equivalent to 3 weight percent $\mathrm{SO}_{4}^{2-}$ in the sludge for a glass containing 30 weight percent sludge.) Although Hanford sludges are expected to contain less sulfate than the amounts added in the experiments, techniques for prevention of sulfate phase separation from the glass will continue to be investigated.

\section{Fixation of Sludge Wastes in Glass}

An evaluation of sulfate-free glass formulations continued during the report period. Glass formulations found suitable for immobilization of synthetic Redox sludge at $1200^{\circ} \mathrm{C}$ were tested for application to fixation of Purex sludge. (The composition of synthetic Purex sludge is given in Reference 1.) Dense, homogeneous glasses resulted from melting all of the formulations tested. A qualitative judgment of the viscosities at $1200^{\circ} \mathrm{C}$ indicated that the Purex sludge melts were much less viscous than the corresponding Redox sludge melts. In most cases the Purex sludge glass viscosities at $1200^{\circ} \mathrm{C}$ were judged to be possibly too low for a continuous melting operation. Thus, a lower furnace operating temperature $\left(1000^{\circ}\right.$ or $\left.1100^{\circ} \mathrm{C}\right)$ may be necessary to convert purex sludge to glass utilizing the same formulations used for glassification of Redox sludge. Alternatively, when processing Purex sludge, a chemical additive that increases viscosity could be fed in with the mixture that is normally used for fixation of Redox sludge. 
In work during the near future, optimization of high and low temperature glass formulations for fixation of Purex and Redor sludges wil continue. Viscosities, resistivities. and devitrification behavior of selected glass formulas will be determined. Testing will begin for fixation of actual sludge samples.

\section{Other Immobilization concepts}

The objective of this activity is to identify, develop. and evaluate alternative processes (other than the Aqueous Silicate or Silicate Melt processes) for conversion of Hanford high-level waste to immobile forms suitable for longterm storage.

The primary immobilieation techniques to be investigated in the laboratory include, but are not limited to:

- Glass sintering

- Concrete

- Pressed concrete (at hot and ambient temperatures)

In previous work scouting studies to determine the application of a process for sintering synthetic sludge into a glass matrix were initiated.

\section{Glass Sintering - M. J. Kupfer}

Previous work has shown that sintering synthetic sludge waste with powdered glasses results in a product form that exhibits low strontium leach rates but high rates for cesium. (I) Recently, sintering of sludge with partially crystalline crushed basalt rock was shown to be a more effective technique for fixation of cesium. Basalt is readily available in the Hanford area. A 50:50 pressed $(20,000$ psi) mixture of basalt ( -325 mesh) and synthetic Redox sludge powder 
sintered best in the range $1100-1200^{\circ} \mathrm{C}$. Purex sludge-basalt mixtures sintered about $100^{\circ} \mathrm{C}$ lower. Leach rates (in deionized water at $25^{\circ} \mathrm{C}$ ranged from about $10^{-5}$ to $10^{-3} \mathrm{~g} / \mathrm{cm}^{2}$-day after four days leaching when based on cesium. These rates are still about a factor of 10 to 100 higher than rates for clay sintered products but are 10 to 1000 times lower than rates for glass sintered products. (1) Leach rates based on strontium are in the range $10^{-6}$ to $10^{-5} \mathrm{~g} / \mathrm{cm}^{2}$-day or about the same as for glass and clay sintered forms.

Radionuclide Removal studies

This activity concerned with devising, developing, and demonstrating processes for removal of all long-lived radionuclides from Hanford salt cake solutions and, possibly. from terminal liquoxs. The overall objectives are to develop and demonstrate techrology for partitioning such high-level wastes into a small volume of highly radioactive waste requiring further immobilization for long-term storage and a large volume of chemical or very low-level wastes which can be safely stored or disposed of by inexpensive means. current studies are focused on:

- screening and testing, with synthetic waste solutions containing appropriate radiotracers, vaxious soxption and ion exchange processes and procedures for removal of ${ }^{137} \mathrm{Cs},{ }^{90} \mathrm{Sr}$. 29 Tc, and actinides.

- Testing cadionuclide removal procedures with actual waste solutions as they become available. 
Sorption of ${ }^{90} \mathrm{Sr}$ on Sandia Titanate Resin - W. W. Schulz

Results obtained previously, both at Hanford and at Sandia Laboratories, Albuquerque, New Mexico, have demonstrated that Sandia Titanate exchanger ( $\mathrm{Na}\left[\mathrm{Ti}_{2} \mathrm{O}_{5} \mathrm{H}\right]$ ) has a great affinity for uncomplexed ${ }^{90} \mathrm{Sr}$ and other cationic radionuclides in alkaline salt cake solutions and terminal liquors. An attempt to estimate the capacity of the titanate exchanger for sorbing ${ }^{90} \mathrm{Sr}$ from actual salt cake solution was made this quarter. This experiment involved passage of salt cake solution obtained by water dissolution of material from Tanks 102-SX and 103-SX tanks through a 2-ml bed of titanate at the rate of five bed volumes per hour. Approximately 135 bed volumes of solution were passed before the run was prematurely terminated because of the absence of required radiation monitoxing and analytical personnel. This capacity determination will be completed when striking workers return to work at Hanford.

\section{Stoichiometry of "Strontium Phosphate" Precipitates -}

W. W. Schulz

Precipitation of inert strontium phosphate from salt cake solution and terminal liquors offers a means of removing ${ }^{\circ} \mathrm{Sr}$ and actinides from such solutions. Experiments were conducted to determine the composition (strontium and phosphate content) of the strontium phosphate precipitate as a function of the composition of the solution from which it was precipitated. In these statistically designed tests, solutions having compositions of 5.6 to $4.1 \mathrm{M} \mathrm{NaNO}_{3}, 0.1$ or $1.0 \mathrm{M} \mathrm{NaOH}, 0$ or $0.25 \mathrm{M} \mathrm{Na}_{2} \mathrm{CO}_{3}, 0.01$ or $0.1 \mathrm{M} \mathrm{Na}_{3} \mathrm{PO}_{4}$ were spiked with $0.015 \mathrm{M}$ $\mathrm{Sr}\left(\mathrm{NO}_{3}\right)_{2}$. The resulting precipitate was digested 60 minutes at $25^{\circ} \mathrm{C}$, centrifuged, and washed with several small volumes of water. Subsequently, the washed precipitate was dissolved with $6 \mathrm{MHCl}$, and the resulting solution was analyzed for 
strontium and phosphate. Data from these studies have not yet been subjected to detailed statistical analysis. Qualitatively, however, the $\mathrm{Sr} / \mathrm{PO}_{4}$ mole ratio for precipitates produced in most cases, especially from solution which contained $0.1 \mathrm{M} \mathrm{Na}{ }_{3} \mathrm{PO}_{4}$, ranged from 1.0 to 2.0 ; for the expected compound $\mathrm{Sr}_{3}\left(\mathrm{PO}_{4}\right)_{2}$, the $\mathrm{Sr} / \mathrm{PO}_{4}$ mole ratio is 1.5 . Precipitates having a $\mathrm{Sr} / \mathrm{PO}_{4}$ mole ratio of about four were obtained from solutions containing $0.01 \mathrm{M} \mathrm{Na}_{3} \mathrm{PO}_{4}$ and $0.25 \mathrm{M} \mathrm{Na} \mathrm{CO}_{3}$. Under these latter conditions, presumably both $\mathrm{Sr}_{3}\left(\mathrm{PO}_{4}\right)_{2}$ and Srco precipitated. Data from these studies will be used to help define requisite flowsheet conditions for scavenging of ${ }^{90} \mathrm{Sr}$ from actual waste solutions.

Headend/Tailend Ozonation Procedures - W. W. Schulz

Unidentified organic ligands which complex ${ }^{90} \mathrm{Sr}$ and prevent its adequate removal by scavenging and/or ion eschange techniques are known to be present in some terminal liquors (e.g. the Tank 110-s solution) and may later be found in some salt cake solutions. Previously reported scouting studies with diluted Tank 110-S 1iquor indicated that these organic impurities could be oxidatively destroyed by treatment with such reagents as $\mathrm{H}_{2} \mathrm{O}_{2}, \mathrm{KMnO}_{4}, \mathrm{Na}_{2} \mathrm{~S}_{2} \mathrm{O}_{8}$, and ozone. ozone is the currently preferred oxidant because it can be readily and inespensively generated on site from air or oxygen and because its use does not result in the formation of objectionable solids. Accordingly, intensive studies were started this quarter to develop and demonstrate workable headend and/or tailend ozonation procedures for use with Hanford solutions. These studies were hampered by the current limited availability of actual waste solutions known to contain complexants and by the unavailability of analytical personnel to perform ${ }^{9} \mathrm{Sr}$ analyses. 
Listed in TableIII are conditions and results of ozonation - scavenging tests with synthetic waste solutions containing varying amounts of partially decontaminated nearterminal liquor from Tank 110-S. Previous to these tests, $137 \mathrm{Cs}$ had been removed from the Tank 110-S liquor by passage through five Duolite ARC-359 beds, and ${ }^{\circ}{ }^{\circ} \mathrm{Sr}$ had been partially removed by passage of the solution through two titanate beds. This treatment removed 298 percent of the ${ }^{90} \mathrm{Sr}$ (from 16,000 to $250 \mathrm{\mu Ci} / 1$ iter): the other 2 percent of the ${ }^{9} \mathrm{Sr}$ was tightly complexed, presumably by one or more organic ligands. Results of scavenging tests made with the various waste solutions (Table III) prior to ozonation confirmed the existence of complexed ${ }^{90} \mathrm{Sr}$ in these solutions.

White solids (later identified as $A I(O H)_{3}$, bayerite) precipitated when Feeds 2 and 3 (Table III) were ozonated for three to six hours at $75^{\circ} \mathrm{C}$. Prolonged bubbling of air through Feeds 2 and 3 converted hydroxide to carbonate ion and resulted eventually in lowering the solution $\mathrm{pH}$ to the point where some of the soluble aluminate ion was converted to solid $\left.\mathrm{Al}_{(\mathrm{OH}}\right)_{3}$.

Although not measured directly. solution analyses before and after ozonation indicate the $\mathrm{Al}(\mathrm{OH})_{3}$ precipitate carried down substantial amounts of ${ }^{90} \mathrm{Sr}$. For these cases, presumably, ozonation destroyed the organic complexant and made the strontium available for sorption on the solid aluminum compound. Tests are now under way with ozone generated from oxygen; this approach should eliminate reaction of hydroxide with $\mathrm{CO}_{2}$ and precipitation of $\mathrm{Al}(\mathrm{OH})_{3}$. 
TABLE III

SCAVENGING OF ${ }^{9}$ Sr FROM OZONATED ALIRALINE WASTE SOLUTIONS ${ }^{*}$

\begin{tabular}{|c|c|c|c|c|c|c|}
\hline \multirow{3}{*}{$\begin{array}{l}\text { Exp. } \\
\text { No. }\end{array}$} & \multirow{3}{*}{$\begin{array}{l}\text { Eeed } \\
\text { No. }\end{array}$} & & & \multicolumn{3}{|c|}{${ }^{20} \mathrm{Sr}, \mathrm{CI} / \mathrm{Iiter}$} \\
\hline & & \multicolumn{2}{|c|}{ ozonation Conditions } & Before & After & After \\
\hline & & Timen $h r_{0}$ & Teme, ${ }^{\circ} \mathrm{C}$ & Ozonation & Qzonation & Scavenging \\
\hline 1 & $1^{b}$ & \multicolumn{2}{|c|}{ Not azonated } & 23.9 & & 2.82 \\
\hline 2 & 1 & 1 & 25 & 23.9 & 20.5 & 10.1 \\
\hline 3 & 1 & b & 75 & 23.9 & 24.7 & 0.41 \\
\hline 4 & $I^{62}$ & 1 & 75 & 23.9 & 22.1 & 0.38 \\
\hline 5 & 1. & 1 & 90 & 23.9 & 13.2 & 0.33 \\
\hline 6 & $2^{4}$ & \multicolumn{2}{|c|}{ Not ozonated } & 177. & & 202. \\
\hline 7 & 2 & 5 & 75 & 177. & 0.3 & 0.24 \\
\hline 8 & $3^{E}$ & \multicolumn{2}{|c|}{ Tor ozonated } & 121. & & 83.6 \\
\hline 9 & 3 & 3 & 75 & 121. & 14.2 & 5.77 \\
\hline
\end{tabular}

Air concaining 0.5 vol: $0_{3}$ bubleled at a rate of 21.51 iter/minutes through indicated waste solutions at indicated times and temperatures. portions of the waste solutions before and after ozonation made 0.025 M $\mathrm{H}_{3} \mathrm{PO}_{4}$ and $0.0075 \mathrm{M} \mathrm{SP}^{2}\left(\mathrm{NO}_{3}\right)_{3}$ resulting precipitate digested 60 min at $25^{\circ} \mathrm{C}$.

$b_{3.9} \mathrm{MNaNO}-\mathrm{U}_{0} \mathrm{MNaNO} \mathrm{MNO}_{2}-0.2 \mathrm{MNOH}-0.1 \mathrm{MNaA10}-0.15 \mathrm{MNa}_{2} \mathrm{CO}_{3}-$ $0.05 \mathrm{M} \mathrm{Na}_{2} \mathrm{PO}_{4}-0 . \overline{0} 15 \mathrm{M} \mathrm{Na}_{2} \mathrm{CrO}_{4}$

Same as solution 1 except 1.0 NaOH

$d_{2.05 M \mathrm{NaNO}_{3}-0.61 \mathrm{MNOOH}-0.50 \mathrm{MNaA10}}-0.37 \mathrm{M} \mathrm{NaNO}_{2}$

$e_{2.9} \mathrm{MaNO}_{3}-0.87 \stackrel{\mathrm{M}}{\mathrm{NaOH}}-0.71 \stackrel{\mathrm{MNaAlO}}{2}-0.53 \stackrel{\mathrm{M}}{=} \mathrm{NaNO}_{2}$

Work in the nest report period will continue to focus on development of adequate headend/tailend ozonation procedures for removal of organic complexants from terminal liquors and/or salt cake solutions. Because of the unavailability of actual waste solutions, it is anticipated that most of the ozonation studies will be done with synthetic waste containing known amounts of various chelating agents. It is also expected that tests will resume to determine capacity of Sandia ritanate sorbent for sorbing ${ }^{\circ} \mathrm{Sr}$ from actual salt cake solution. In calendar year 1977, construction and 
operation are planned for a hot cell Radionuclide Removal pilot Plant; initial equipment design is expected to begin during the next report period.

\section{Solvent Extraction - G. S. Barney}

The separation of sodium salts from radionuclides using liquid-liquid extraction was studied further. The fractions of sodium, cesium, and strontium remaining in the raffinate at various stages were calculated for countercurrent extraction of salt cake solution. Extraction coefficients for $1.0 \mathrm{M} t$-buty 1benzo-15-crown-5 in chloroform and $0.77 \mathrm{M}$ t-butylbenzo-15-crown-5 in 1,2,4-trichlorobenzene were used in the calculations. It was found that the extraction coefficient for sodium must be $\geq 0.15$ (at $3-5 \mathrm{M} \mathrm{Na}$ in the aqueous phase) so that the phase ratio, organic/aqueous, can be reasonably low ( $\leq 3)$. This requirement eliminated diluents in which t-butylbenzo-15-crown-5 has a low solubility (i.e., 1,2,4-txichlorobenzene, 1-octanol, o-dichlorobenzene).

The extractant, t-butylbenzo-15-crown-5 in $1,2,4-$ trichlorobenzene solvent extracts $\mathrm{NaAlO}_{2}$ rather strongly. Therefore, this extractant appears to be useful for separation of sodium salts from radionuclides in terminal liquor which contains large amounts of $\mathrm{NaAlO}_{2}$. All the major types of sodium salts contained in stored wastes appear to be extractable with this crown ether.

The solubility of $t$-butylbenzo-15-crown-5 was measured in water and in a synthetic salt cake solution. No crown ether could be detected in either aqueous solution using gas chromatography. Since the detection limit for the analysis was $0.001 \mathrm{M}$, the solubility of this crown ether in aqueous solution is very low. The solvent loss for an extraction system using this crown ether wiil, therefore, be low. 
Process Development Studies - J. E. Hammelman

Engineering design calculations continued for the processing step of cesium removal by Duolite ARC-359 (Diamond Shamrock Chemical Company, Cleveland, Ohiol ion exchange resin. A working summary of these studies was issued that includes:

- A review of existing laboratory data related to the removal of cesium from a salt cake solution by Duolite ARC-359, (Some of this data was presented in a previous quarterly report. (1),

- Flowsheet calculations for both fixed bed and continuous countercurrent operations.

- Recommendations for further chemistry and engineering laboratory tests. 
LONG TERM MANAGEMENT OF CONTAMINATED

SOILS AND SEDIMENTS

CONTAMINATED SEDIMENT CONTROL

Contaminated Sediments - R. R. Fecht

The activity objectives are (1) to characterize various intermediate and low-level fission product waste disposal facilities with respect to the fission products and straticgraphy, and (2) to determine the migration or potential migration of the fission products in the sediments at waste disposal facilities.

Radionuclide concentrations for approximately 110 sediment samples were determined for the U Pond and the Redox Ditch. The analytical results indicated concentrations of actinides and fission products at the same levels as found in previous determinations.

The geophysical logging of $240 \mathrm{crib}$ wells.is 60 percent complete (gamma radiation logging, 100 percent: neutron logging, 60 percent: and density logging, 20 percent). The strip logs will be used in conjunction with geologic maps of cross sections to locate areas of radionuclide migration.

Actinide Trench Characterization - S. M. Price and M. M. Kilisgaard

The objective of this activity is to characterize the chemistry and distributions of the actinides and their compounds, particularly plutonium and americium, present in sediments underlying liquid waste disposal facilities in the 200 Areas of the Hanford Reservation.

There is a need to ensure that no hazard exists to the general public from actinide waste manament operations. 
Since the initiation of the Actinide Trench Characterization program three test holes have been arilled under conditions of total containment-one at the 216-z-9 Trench and two at the 216-z-1A Trench. Analyses of samples from these holes have shown that the greatest measured concentration of $239 \mathrm{Pu}, \sim 10^{6} \mathrm{HCi} / \mathrm{liter}$ of seaiment, occurs in both facilities just below the point of release of the waste 1iquid. The concentration drops off from this point to $<10 \mu \mathrm{Ci} /$ iter of sediment at the 10-meter depth. Examination of samples revealed two types of plutonium occurrence, the "particulate" and the "nonparticulate," responsible for this distribution. The particulate-type was "filtered" out with the upper I $\mathrm{m}$ of the sediment column, accounting for the high concentration of plutonium in this region: the nonparticulate-type penetrated deeper within the sediment profile and was deposited in association with silicate hydrolysis of the sediment fragments. The plutonium distribution determined at the sites is discussed in more detail in ARH-SA-232. Neutron pulsing of the two wells at the 216-z-1A Trench indicates that the probabilty of attaining criticality at the site is essentially noneristent if left in an undisturbed state. A dual-walled core barrel was designed, constructed, and tested which enables test wells for neutron pulsing to be employed more economically than the method previously employed at the 216-z-1A Trench. In addition, tools for obtaining representative sludge samples have been designed and tested.

During the report period, totally contained drilling of one well was completed at the head of the 216-z-12 Irench to a depth of $12 \mathrm{~m}$ below the ground surface. At the 12-m depth contamination was sufficiently low to allow deepening of the test hole by open driling. Consequently the containment hood was moved to the head of the 216-z-1A(b) Trench where 
drilling was initiated. Driling at the 216-z-1A(b) site was discontinued due to the craftsmen's strike. A dualwalled core barrel was emplaced in the z Trench complex. The core barrel will be utilized to establish background levels for neutron pulsing instrumentation. Modification of sludge sampling tools was completed and tests indicate that two tools are capable of obtaining representative samples of the contents of Tank 361-z.

Decontamination - Immobilization - G. M. Holter

The objectives of this activity are to develop concepts for cleaning up contaminated vegetation, sediments, effluents, and buxial grounds, and then immobilizing and storing the retrieved material.

Preliminary modifications of the mobile vacuum cleanup system are about 90 percent complete. Work on this unit has been halted due to the HAMTC strike.

A study for characterization of liquid laundry effluents was outlined and BNW is performing the study under ARHCO direction. An interim report was completed in May containing: (1) preliminary characterization results, (2) a proposed treatment system for the liquid effluents, and (3) technical information to assist in the design of such a treatment facility.

A series of jar tests was also carried out to determine the effects of various treatment options on solids removal. The HAMTC strike has slowed work on the study, but has not affected its scheduled completion. To demonstrate the process and provide further design data, the treatment study will be followed by laboratory evaluation of the system. 
Sediment Stabilization - P. J. Wiater

The objectives of this activity are to (1) demonstrate that radionuclides on surfaces of all types ( $\%$. . pristine desert land, worked land, and burned-over areas) can be affixed by chemical agents in combination with ground covers such as cheatgrass: (2) demonstrate that subsurface radionuclide-contaminated regions can be affixed by chemicals such as asphaltic emulsions: (3) demonstrate that subsurface pipe and tank leaks can be contained by grouting; (4) demonstrate that contaminated ponds can be affixed with chemical agents; and (5) investigate new affixing agents. preadditives, and methods of injection.

The contaminated Redox Pond was backfilled in FY 1975. Approximately $1200 \mathrm{~m}^{2}$ that were contaminated with greater than $1 \mathrm{nCi}$ of plutonium per gram of soil were affixed with cationic asphalt emulsion before they were covered with $1 \mathrm{~m}$ of new soil. The entire pond was then seeded with cheatgrass and mulched. Twenty thousand square meters bordering the pond were stabilized with a latex emulsion, M166 (Dowe11 Division of Dow Chemical Company), to prevent loose soil from blowing into the seeded area. These tests appear to be successful in that no measurable amount of erosion has occurred.

Six dry wells $(15.24 \mathrm{~cm} \times 3.05 \mathrm{~m})$ were installed at the S-16 Redox Pond - three in the asphalt-treated area and three in the untreated area. These wells will be used as measurement points to determine radionuclide migration below the asphalt and if asphalt can stop the upward migration of radionuclides. Two moisture probe wells were installed in the Redor Pond to conduct moisture studies.

The movement of radioactivity in the affixed and nonaffixed areas of $\mathrm{S}-16$ Redox Pond were measured during this period. Four separate readings indicate no significant 
changes of the activity. A plutonium measurement by "passive" activation technique using copper discs was calculated to be less than $16 \mathrm{nCi}$ of plutonium per gram. This region of Redox Pond has been analyzed and reported on by LFE Environmental Laboratory.

A test plot $\left(4000 \mathrm{~m}^{2}\right)$ was burned, seeded with cheatgrass, and sprayed with M166 to determine the affixant's ability to stabilize a burned-over area in germination of the cheatgrass. The area is now covered with cheatgrass and some tumbleweeds have appeared. The success of this test will depend on whether the cheatgrass has sufficient growth to propagate itself this rall.

Trace elements of LiCl were added below the S-11 biobarrier test facility and the experimental culverts seeded with tumbleweed. Plant uptake studies have been initiated and will be completed during the transition FY 1976. Neutron moisture readings were begun in March 1976.

Field tests were conducted to determine the effectiveness of sealing an underground pipe leak by grouting through injection wells. The 102-AX Dresser Coupling (Dresser Industries. Incorporated) located $3 \mathrm{~m}$ below grade level was grouted with 12,500 liters of cationic asphalt emulsions though four injection wells evenly spaced around the area to be covered. Well readings taken prior to the grout were compared with those taken after the leak was immobilized. Probe readings in the four wells used for injection show no increase in activity that would require immediate action. The readings in the dry wells have shown no increase in activity. A measurement of plutonium concentration around the Dresser Coupling has been calculated to be less than $31 \mathrm{nCi}$ of plutonium per gram.

A new vibratory drilling tool was secured to test fast drilling techniques. The first test was successfully demonstrated at the 155-Tx diversion box leak detection study. 


\section{ENVIRONMENTAL IMPACT TECHNOLOGY}

\section{HYDROLOGY}

Groundwater Hyarology - R. A. Deju

This activity is aimed at obtaining the hydrologic data needed to charactexizo the Hanford groundwater flow regime, developing prediotive models of groundwater flow, and developing mangement and control strategies to avoid groundwater contamination.

The groundwater well-monitoring network will be updated following a routinc maintenance schedule as per the 200 Areas and 600 Area well inventories. These two inventories have been completed ard are being reviewed. They outline the present well-monitoring network and all proposid changes.

During the report period, nine wells were drilled throughout the Reservation to elucidate the geology and hydrology of the basin. These weIls will furnish some of the data needed to characterize the hydrologic properties of the subsurface. A pathline model has been developed, tested, and implemented on the computer. Analytical codes have been developed to allow utilization of the pathine model to compare results obtained from this against semianalytical solution. Discrepancies have been found between the pathline model and the analytical solutions only near waste disposal sources. These discrepancies can be rectified by using a closer gradient interpolation scheme.

Work continued in the development of methods to sumnarize arrival time distributions of contaminated fluids. A preliminary draft of a document entitled "Evaluating the Environmental Consequences of Groundwater Contamination" was completed and is being reviewed. Two computer codes, STREAK and PATH, have been developed and tested. These programs 
can be used to obtain arrival time distributions of contaminated plumes for complex subsurface pollution flow systems.

The data to be used as input in the verification and sensitivity studies of the transport code were assembled. The transport code was used to predict tritium contaminant movement from 1976 to 1986.

The conversion of the code to calculate transmissivity distribution from the PDP-9 to the PDP-11/45 (both Digital Equipment corporation) computer is complete. Preliminary tests indicate that this conversion allows a reduction in running time of the transmissivity program from 6 hours to 20 minutes.

A report on the Variable Thickness Transient sensitivity study has been completed and is being reviewed.

Four documents covering the theory utilized in the transmissivity, saturated flow, partially saturated flow, and contaminant transport models were prepared during the quarter. One document has been issued and the remaining three will be issued during transition FY 1976.

Work continued on the electric log study, including examination of data from 12 well structures. During the quarter emphasis was placed on preparing a preliminary report on the procedures to be followed in interpreting the electric logs. This report, entitled "Techniques of Geophysical Logging of the Hanford Reservation" was prepared by the College of Engineering, Washington State University, and has been reviewed by the Atlantic Richfield Hanford company.

Offsite Migration - R. A. Deju

This activity is aimed at determining the concentration and ultimate fate of any radionuclides that may be present or could potentially contaminate the confined aquifers underlying the Hanford Reservation. This information is needed 
assure isolation of Hanford radioactive wastes from any users of water from the confined aquifer outside of and adjacent to the Hanford Reservation.

During the report period a research report was completed on the regional geology and hydrology of the uppermost confined flow system underlying the Hanford Reservation ("Hydrogeology of the Uppermost Confined Aquifers underlying the Hanford Reservation,"ARH-SA-253). As a result of this study it was determined that the uppermost confined aquifers may be breached along the anticlinal axis extending through Gable Mountain and Gable Butte. The extent of breaching in the area of Gable Pond and West Lake is presently being examined. Two new wells penetrating the uppermost confined aquifer were completed in this area and have been used for chemical, hydrologic, and heat testing. The piezometric head in the confined aquifers appears, at present, to be in equilibrium with the water level in west Lake. Analyses of various radiological and chemical constituents were conducted on samples taken from Gable Mountain Pond, West Lake, and the aquifers underlying these surface waters. Analyses have been completed for tritium and ${ }^{14} \mathrm{C}$; preliminary results have been obtained for some of the other radiocontaminants. No plutonium has been detected to date in the confined aquifer, Gable Pond, or West Lake. Tritium levels in West Lake are anomalously high and work is proceeding to identify the source of this contamination.

Work continued to evaluate the feasibility of constructing the preliminary data base needed to apply a finite-element version of existing transport codes to the uppermost confined aquifers. During the current report period, geologic data were examined to determine the boundaries required for modeling the confined aquifer. Information was complied as to location of possible recharge and discharge boundaries. 
Radionuclide Migration in Groundwater - R. A. Deju

This activity is dedicated to definition of the main channels of radionuclide migration through the groundwater pathway and to reduction of radionuclide transport throughout these channels. Such objectives are obtained by conducting geological, geophysical, and geochemical studies.

During the current report period samples from 115 wells were analyzed geologically at very close intervals and the results were compiled into strip logs. All the geologic information on each well is documented in a report being prepared by Mr. W. K. Summers and Associates, consultants. This report is presently being reviewed. The strip logs show some discrepancies from previous geologic interpretations of the Hanford Reservation. These discrepancies will form the basis for further work.

Effort continued in interpreting the results of gravity readings taken on 350 stations over the Hanford Reservation. A report on this work by Dr. B. H. Richard, Wright state University, consultant, is being prepared and will be completed during the next quarterly report period. This report is aimed at delineating potential sites of entrance of the ancestral Columbia River into the Hanford Reservation. During the current report period, work was also continued in refining a three-dimensional model of the Hanford Reservation using gravity data. The model will assume that the subsurface of the Reservation consists of unsaturated, unconsolidated material separated by the water table from saturated, unconsolidated material. The lower boundary of the saturated zone is assumed to be the basalt surface. This three-dimensional model will assist in evaluating not only the location, but also the thickness of permeable buried streams significant in the transport of radionuclides leaving the high-level waste storage areas. 
The gravity and strip log studies are aimed at defining the most transmissive channels throughout the subsurface. These studies are combined with a geochemical program to assess the interactions that occur as water containing radioactive wastes migrates through them. As part of the geochemical study, work proceeded during the report pexiod in outlining the parameters that need to be measured to understand sediment waste reactions. An understanding of these chemical mechanisms should provide a rational means of developing groundwater monitoring systoms and developing engineered responses to specific contaminant transport problems.

During the forthcoming report period, work will proceed in the geologic, geophysical, and geochemical areas with emphasis on data interpretation.

Long-Term Groundwater Management - R. A. Deju

This activiti is aimed at idontifying potential ways in which high-1evel wastas uan coms in contact with groundwater. and examining the potential impat to the groundwater regime of past and wojected activitios in the high-1evel-wastw storage axeas.

To accomplishactivity goals, a program was initiated to evaluate computer models and data requirements for long-term groundwater management within the waste storage areas. Computer modeling is an ideal tool for predicting the behavior of the Hanford groundwater flow system under a variety of stresses. As part of this a rather comprehensive analysis was conducted of finite element techniques as applied to groundwater flow problems. About 500 computer codes useful in modeling saturated, partially saturated, and multiphase flows were analyzed. Thirty of these codes (Table IV) available both offsite and at Hanford appear to offer the most promise for our modeling efforts. A document entitled "Conceptual and Mathematical Modeling of the Hanford Groundwater Flow 


\section{TABLE IV}

OFFSITE AND ONSITE FLOW MODELS OF POTENTIAL USE AT HANTORD

Fluid Flow

\begin{tabular}{|c|c|c|c|c|}
\hline \multicolumn{3}{|c|}{ Saturated } & \multirow[b]{2}{*}{$\begin{array}{c}\text { Partia11y Saturated } \\
\text { (static Aix, Dynamio } \\
\text { Water Phase) } \\
\end{array}$} & \multirow[b]{2}{*}{$\begin{array}{c}\text { Multiphase } \\
\text { (Dymamic Gas } \\
\text { and Water low) } \\
\end{array}$} \\
\hline Confined Aquifer & $\begin{array}{l}\text { Unconfined Aquifer } \\
\text { (Free Surface } \\
\text { Representation) }\end{array}$ & $\begin{array}{l}\text { Boussinesq } \\
\text { Approsimation }\end{array}$ & & \\
\hline INTERA-HCTM & INTERA-HCTM & HANEORD-VTT & COLORADO FD & INTERA-GWM \\
\hline DAVIS FE & DAVIS FE & COOLEY & SEGOL FE & KANSAS-GREEN \\
\hline TRUMP & USG3 $(3-D)$ & SPASM, III. & OAK RIDGE FE & ARCO-IMPESS \\
\hline FLUMP & ELUMP & PINDER & NEUMAN E'E & \\
\hline SOPH & WALES, Eng. & SAMMTR-Fr. & USFLW, IST. & \\
\hline \multirow[t]{4}{*}{ MICHIGAN } & MASS, Isr. & MASS, Isr. & INPIL, Fr. & \\
\hline & & WEBER & & \\
\hline & & MICHIGAN & & \\
\hline & & HIGH PIAINS & & \\
\hline
\end{tabular}


Regime," ARH-ST-140, is being prepared which sumarizes the hydrologic model and data requirements for Hanford and shows how offsite and onsite models should be incorporated in a comprehensive long-term groundwater management plan. Areas where significant deficiences are noted in the computer modeling effort will be slated for additional development work. By recognizing all data requirements and having available the most suitable computer systems to handle this information, maximum credibility will be achieved in predictive effort.

In order to have adequate data regarding the total flow of water through the unconfined aquifer underlying the high-level-waste storage areas, work was continued to define the geohydrological characteristics of the cold creek Valley. This work involved arilling three research wells west of the 200 Areas plateau. Two wells have now been completed, and the third one is 80 percent complete. These wells will also serve to evaluate the impact on Hanford operations of increased irrigation west of the Hanford Reservation boundary.

TRANSPORT

Moisture Transport Studies - P. G. Easley

The objectives of this activity are (1) to describe mathematically nonisothermal flow of liquid, vapor, and gas in partialy saturated porous media: (2) to develop a numerical algorithm for solving the nonisothermal partially flow equation: (3) to complete the field tests needed to verify moisture movement in partially sediments within the 200 Areas Control zone: and (4) to relate the extent of moisture movement from precipitation to radionuclide transport within the vadose zone.

The moisture distribution in two lysimeters located about a mile south of 200 East Area has been determined routinely since January 1972. The data have shown that the 
moisture entering the ground from precipitation moves downward to a depth of 2 to $4.5 \mathrm{~m}$ and then back to the ground surface, probably in the vapor phase, and into the atmosphere. The maximum moisture content is usually reached in January or early February ( 12 to 15 volume percent), and the minimum in late september to mid-october ( 3 to 5.5 volume percent). The average moisture content below the 5.5-meter depth is 6.0 volume percent.

Matrix potential and temperature profiles from the surface to the water table were recorded. Equations describing the nonisothermal flow of water, vapor, and gas in partially saturated sediments have been calculated. Progress was made on an algorithm for the solution of these equations using orthogonal collocation on finite elements and Gear's method.

\section{Lysimeter Measurements}

The sediment moisture profiles for the open- and closedbottom lysimeters were measured twice in April and once a month in May and June. There was little apparent moisture movement, probably because the weather during the report period was somewhat cooler and drier than average. Further instrumentation of the open-bottom lysimeter is progressing.

Design of new lysimeter sites was postponed, but evaluation of alternatives will continue.

Mathematical Modeling

A subprogram for MPHASE with interactive input capability was completed by Boeing Computer Sciences, Richland. Further development work on MPHASE will be initiated in July 1976.

In May and June two computer programs developed by INTERA-Environmental Consultants, Ltd." were evaluated for their use in moisture transport problems typical of Hanford. These programs were developed for two-phase flow through an oil field. One of the two programs tested was numerically stable and gave reasonable results. A decision will be made 
by, or soon after, the next report period (transition FY 1976) as to which of these two methods should be followed:

1. Continue development of MPHASE, which can now be used in only one dimension, but which utilizes a more complete set of equations (takes vapor-phase moisture transport into account).

2. Utilize one of the codes developed by INTERA, perhaps with minor modification. During transition FY 1976 both development of MPHASE and testing of another INTERA program will take place, because comparison of the two will aid in determining the validity of both programs.

\section{Moisture Transport Properties of Sediments}

During the report period personnel at Battelle-Northwest studied the variation with temperature of fluid conductivity and retentivity of sediment samples. A controlled-environment chamber was specified and purchased, but installation was slowed by the strike.

Biotic Transport - V.A. Uresk

The impact of waste management facilities and operations on the environment must be determined and evaluated. Biological mechanisms with the potential for concentrating, releasing and/or dispersing radioactive materials must be anticipated so that control procedures can be developed. To accomplish these objectives, biological agents interacting with waste sites must be defined, their potential for concentrating and dispersing radionuclides must be evaluated, and technology to restrict transport of contamination from 200 Areas waste sites must be developed. 
Radionuclides in Soil - Plant systems

This activity is providing quantitative information concerning the ecological fate and behavior of radionuclides in the soil-plant system. The information will be used in the formulation and maintenance of ecologically sound waste management practices.

Growth-chamber studies showed that the chemical form of transuranic wastes affects their uptake by plants from Hanford soils. Plant uptake of transuranics increased in the presence of the chelates ethylenediaminetetraacetic acid (EDTA) and diethylenetriaminepentaacetic acid (DTPA) and salts of several organic acids.

Plant uptake of technetium by tumbleweed and cheatgrass was measured for five Hanford soils. Samples were harvested at one-, two-, and three-month intervals. Uptake at the three-month harvest ranged from 23 to 82 percent and from 10 to 69 percent of the added technetium for tumbleweed and cheatgrass, respectively. Concentration ratios based on the estimated soil concentration during each harvest period ranged from 76 to 357 and from 54 to 421 in tumbleweed and cheatgrass, respectively.

A growth-chamber study of the effects of soil properties and waste composition on plant uptake of strontium and cesium from five Hanford soils is nearly completed. This information will be used to develop predictive models for estimating radionuclide availability to plants as a function of measurable soil properties and waste chemical form. In addition, the five soils are being analyzed for potentially stable analogs of cesium (cesium, potassium, rubidium, lithium) and strontium (strontium, calcium, barium, magnesium). At the study's conclusion the plant tissues will also be harvested for these same stable analogs. This information will provide a basis for selecting stable elements which, when used as soil amendments, would be effective in reducing the availability of strontium and cesium to plants. 
Radionuclides in Terrestrial Plants and Animals

This activity is providing ecological information about plants and animals inhabiting waste management zones so that their actual or potential role in the exposure, concentration, or transport of radioactive wastes may be anticipated and controlled.

A census of the plants, small mammals, and insects inhabiting study areas near the B-C Crib Control zone and the Redox Swamp was completed.

Information relevant to waste management on the food habits, burrowing behavior, density, position in food chain, and potential for offsite dispersal of contamination was sought.

A study which assessed the potential for invasion of buried wastes and subsequent uptake of radionuclides by roots of specific plants was completed. The deepest-rooted plants found were bitterbrush, sagebrush, rabbitbrush, tumbleweed, and hopsage. The maximum rooting depth was Found to be $3.0 \mathrm{~m}$.

Radiochemical analysis of small mammals trapped near $U$ Pond continued to show the highest levels of radioactivity in house mice. So far 51 mice have been surgically implanted with thermoluminescent dosimeters (TLD) and released to the Pond site for later recapture to assess dose rate. Four animals with TLD's were recaptured after 37 days' exposure at the Pond. Analysis of the TLD's showed exposures of $1826 \mathrm{mR}$ and $1329 \mathrm{mR}$ for mice 1 iving in the meadow area between the U-14 and $\mathrm{z}-19$ Ditches and $219 \mathrm{mR}$ and $174 \mathrm{mR}$ for mice living among the trees near the pond.

These dose levels are expected to produce no somatic or genetic effects in the mice. Dosimeters were also placed in the soil along the trapping transects at. 1-meter intervals to a depth of 5 meter. This information will be used to develop a correlation between environmental contamination levels and dose to free-ranging wildife and possibly to man. 
Soil samples which were collected from six burial sites in the 200 West Area are being characterized to determine radionuclide levels in vegetation. The samples were analyzed for texture, $\mathrm{pH}$ organic matter, and micro- and macronutrients. The soils are being related to the vegetation growing on each burial site with respect to age. The soils are sandy loam and loamy sand, averaging about 80 percent sand and 20 percent silt. The $p H$ was high, ranging from 8.2 to 8.6 , which is indicative of the mixing of topsoil with deeper soil when the burial grounds were filled. Nutrients important to plant growth are limiting, which explains the sparse vegetation on most burial sites.

The vegetative cover plots established November 1974 on soil fill overlying the $s-17$ pond showed excellent natural reseeding for the second year of study. The treatments included adding straw only, clay only, and straw plus clay to the study plots. AII treatments were about equally effective in establishing vegetative covers and were about 20 percent higher than the unireated controls. The cheatgrass cover effectively resisted wind erosion.

\section{Radionuclides in Aguatic Biota and sediments}

This activity is defining the pathways of radioactive material, previously discharged to cooling water ponds, through the aquatic food web, including waterfowl.

coots on 200 Areas ponds have been sampled bimonthly since June 1974 to determine seasonal body burden levels. The average concentrations of total body burden-levels of adult coots collected at Gable Mountain, $B$ and $U$ Ponds were 155, 12, and 97 pci/g, respectively; while control coots sampled at the columbia Wildife Refuge near othello, washington, averaged background ${ }^{137} \mathrm{Cs}$ concentrations of $0.26 \mathrm{pCi} / \mathrm{g}$. 
Sampling of coots was discontinued during May so that a study of the effects of chronic irradiation on reproductive success of coots nesting at Gable Mountain Pond would not be disturbed.

At that time information on the clutch size and egg and nestling weights was gathered for 15 nests at Gable Mountain Pond for comparison with data taken from 30 nests located on the Columbia Wildlife Refuge. Eggs were also collected from the nests for radiochemical analysis to determine if radioactivity is transmitted from the adult to the egg.

\section{SEISMOLOGY AND GEOLOGY}

Tank Farm Geology - W. H. Price

The objectives of this activity are to:

- Document the structure and stratigraphy of the partially saturated sediments underlying the 200-Area Tank Farms for use in tank surveillance and tank leak studies.

- Identify significant hydrological and sorption properties of each stratigraphic unit for evaluating the impact of tank leaks on the envixonment.

- Assist Tank Farm surveillance in determining the status of tanks and determining on an as-needed basis the spatial distribution of radionuclides leaked to the environment.

Gamma energy analyses have been completed on all sediment samples collected during the arilling of five ary wells through the Tank 241-T-106 leak. All wells within the vicinity of the tank have been analyzed with a lithium drifted germanium [Ge(Li)] detector to determine the concentrations of the radionuclides present. A ruthenium calibra- 
tion facility has been designed to better calibrate this instrument. The facility will be completed during transition FY 1976.

Boyles Brothers Drilling Company, Spokane, Washington, completed two core weIls in the 200 West Area. These core wells are the first known attempt to continuously core unconsolidated and semiconsolidated sediments utilizing standard mud rotary coring techniques. Core recovery was estimated to be between 85 and 90 percent and data from the core has demonstrated the continuity of major lithologies within the Middle Ringold Formation between tank farms under 200 West Area. Data from the two core wells were incorporated into the tank farm geology maps and cross sections. samples from the core wells are currently being analyzed for mineralogic and hydrologic properties.

Thirteen internal reports were prepared to provide basic geologic information for utilization in evaluating the impact of suspected and confirmed tank leaks. The reports contain 140 detailed geologic maps and cross sections which were prepared with the aid of size and calcium carbonate analyses of over 9400 sediment samples from 427 wells drilled in and around the 200 Areas tank farms.

All tank farm water wells are being constructed in accordance with the state of Washington"s Minimum Water Well standards. The water wells are being perforated from the ground surface to a depth of 6.09 meters (20 feet) and perforated from a depth of $27.432 \mathrm{~m}(90$ feet) to just above the water table [approximately $60.96 \mathrm{~m}$ (200 feet)]. Elevencentimeter $(4.5-i n c h)$ well casing with a packer attached is being run in each well and the packer set near the water table. The annulus between the $11-\mathrm{cm}$ casing and the existing casing is then grouted. 
Geologic maps and cross sections will be drawn for the new 241-AW Tank Farm as soon as the tank excavation is completed. Tank farm water well grouting will continue and should be completed by the end of FY 1976. Reports for the Tanks 241-T-106 and 241-A-104 leak investigations should be nearing completion by the first quarter of FY 1977.

Seismic Studies - K. R. Fecht

The objectives of this activity are: (1) to implement a system for detection of local earthquakes and a plan for evaluation of their impact on major waste containment systems, (2) to establish an inspection system fox verifying the integrity of critical waste-management structures, and (3) to assess the regional tectonic stability with respect to current and long-term waste management plans.

The field mapping of the Wallula Gap purported fault is continuing into the second field season. During the first season the basalt stratigraphy for the Wallula Gap area was determined, and the location for trending the purported fault in the Yellepit pond area was selected. During the report period field investigations of brecciated zones were initiated on the east side of the Gap toward Van sycle canyon.

An immediate response seismic monitoring array to minimize releases of radionuclides to the environment due to earthquakes was laboratory-tested during the reporting period. The geophones were positioned in the field, and field-testing of the equipment was initiated.

one station is being replaced and is needed to locate hypocenters and magnitudes with a higher degree of precision. 


\section{RISK ASSESSMENT}

Hazard Index Plan - I. E. Bruns

The objective of this task is to devise mathematical relationships that equate the toxic substances in waste sites with the "hazards available to man." Such relationships can be used to provide direction as well as develop criteria for control of contamination sources.

An equation was devised as follows:

HA (Hazards Available) = TF (Transport Factors) + HI (Hazard Index)

$$
T F=\log T F_{R_{1}}+T F_{R_{2}} \cdot \cdots T_{R_{m}}
$$

where $R_{\mathbb{M}}$ - . $\mathrm{K}_{\mathrm{In}}$ are routes to man by a series of consecutive pathways.

$$
\begin{aligned}
& T F_{\mathbb{R}_{1}}=\left(P_{a}\right)\left(P_{b}\right)\left(P_{c}\right) \cdot \ldots\left(P_{n}\right) \\
& \left(P_{n}\right)=\text { Eraction transported by mechanism a, b, } n \text { : } \\
& \text { e.g., diffusion from subsurface to surface, } \\
& \text { resuspension, dilution (all are functions of } \\
& \text { time, distance, and conditions such as wind } \\
& \text { speed for resuspension, moisture transport in } \\
& \text { diffusion, etc.). } \\
& \mathrm{HI}=\log \frac{\mathrm{TSC}}{\mathrm{MPC}}=\log \frac{\text { Toxic Substance Concentration }}{\text { Maximum Permissible Concentration }}
\end{aligned}
$$
sions can be arawn: 
- Removing 90 percent of the activity from a given waste site only reduces the HI by one order of magnitude, and since HI's generally are in the 10 to 18 range (for inhalation), reduction of only one still leaves a major problem, since an HI of $O$ is equivalent to maximum permissible concentration. Normally TF's will be reduced possibly one or two orders of magnitude by removing 90 percent of the activity. An acceptable HI for minimum surveillance is estimated to be in the range of 5 to 9 for inhalation depending on the TF's.

- With toxic substances like cadmium, mercury, plutonium, or strontium, one must think in orders of magnitude since these are very toxic substances. For example, $1 \mathrm{~g}$ of the material dispersed throughout a $1-\mathrm{m}$ matrix can give inhalation $\mathrm{HI}^{\prime} \mathrm{s}$ of 7 to 12 . 


\section{ANAIYTICAI METHODS TECHNOLOGY DEVELOPMENT}

\section{ANALYTICAL COMPUTER SYSTEMS}

\section{Subcritical Assembly for Low-Level Fissile Analysis -} W. H. Zimmer

The primary objective of this activity is the analysis of low levels of fissile material. A particular need exists at Hanford for the nondestructive assay of fissile material, in any media, at a level as low as 10 nanograms fissile material (specifically ${ }^{239} \mathrm{Pu}$ ) per gram of sample, a factor of 19 below the maximum fissile concentration for discardable waste. The secondary task of this project is analysis of long-lived betaemitting fission products and nonradioactive elements through the use of standard neutron activation analysis techniques.

The Californium Multiplier $(C F X-40)$ was the neutron source chosen for this project because it is capable of multiplying the spontaneous neutron flux from 40 milligrams of ${ }^{252} \mathrm{Cf}$ to a flux density sufficient to attain program goals in a subcritical assembly. A Delayed Neutron Counter (DNC) will count the delayed fission-product neutrons to determine fissile content of the sample. The neutron flux of the CFX-40 will also activate long-lived beta-emitting fission products and nonradioactive elements, permitting detection of these waste constituents at the part-per-billion level without additional investment of money or manpower. A pneumatic sample-transfer system, using molded capsules as sample-transfer vehicles (rabbits), will connect the CFX-40 with the DNC and other detector equipment.

The Atlantic Richfield Hanford Company entered into a contract with the IRT Corporation for the design and construction of the CFX and the DNC system. A critical path chart for the project was prepared.

Specifications for the californium capsules were finalized and forwarded to Savannah River Laboratories for 
fabrication. A draft of the CFX Safety Analysis Review was started by IRT, which also filed for a license and amendment with the United States Nuclear Regulatory Commission to fabricate and test a water-moderated CFX system. Fuel definition is 50 percent completed, neutronic optimization studies were initiated, and mechanical and electrical designs were started by IRT. The DNC design was completed with both the $\mathrm{BF}_{3}$ tube grid and electronic system designs in progress. All IRT milestones are on schedule. Fabxication of the Reactor Experiments. Inc. pneumatic sample-transfer system is complete and the materials are being transferred to IRT and ARHCO. Because of the strike, all phases of craft work and procurement are not on schedule. This includes installation of 227-liter ballast tanks and procurement of the Scorpio 3000 (Canberra Industries, Inc.) computer system and components for the control system.

Providing craft work and procurement can be completed, the pneumatic transfer system will be installed and tested during the next report period.

\section{ANALYTICAL INSTRUMENTATION DEVELOPMENT}

Radiation Analysis Systems Development - W. H. Zimmer, V. W. Hall, and C. P. McLaughlin

The objective of this activity is the design and application of data acquisition and reduction systems to all phases of nondestructive measurement instrumentation which utilize radioactive emissions.

Radiation emmissions analysis instrumentation and data reduction capability are needed for nondestructive measurement of analytical phases of ARHCO waste management, safeguards, production, scrap recovery, effluent evaluation and control, and quality assurance programs. The radiation emissions analyzed include natural and long-lived radioactive 
decay product measurement as well as short-1ived, induced radiation measurement: $i . e$, neutron activation and $x-r a y$ fluorescence.

\section{Detector systems}

A 10-detector intrinsic germanium detector array for environmental gamma energy analysis of bulk samples such as soils, tumbleweeds, and filters will be purchased from ortec Incorporated. The original detector design by ortec which placed the 10 detectors in a single concentric circle was unacceptable, and a proposal was made for a detector arrangement with two concentric circles containing 5 detectors each.

Gamma, X-ray Data Reduction Systems (GXDR)

Phase 4 update of the GXDR system will be accomplished using a canberra scorpio 3000 system. The equipment will provide pneumatic transfer control for the californium Multiplier, spectral data acquisition, integration of $\mathrm{x}$-ray and plutonium isotopic data reduction, and full GXDR spectra data transfer control. The bid has been approved and the combined feasibility and systems study is awaiting approval.

Transmission of Automatic Radioactive Inventory System (ARIS)-II software program by a multicommunication adapter linkage from the NOVA 1220 (Data General Corporation) computer disc to the NOVA 1200 (Data General Corporation) computer core was demonstrated and placed in service. Time required for reading programs into the computer for data reduction was reduced by a factor of 15 . A program to transfer spectra data to an NS-636 (Tracor Northern, Inc.) analyzer from disc was completed. These achievements are steps required for eventual operation of the NOVA 1220 computer in a sequential mode with Real Time Disc Operating 
System and the Chemical Technology Laboratory Gamma Data Reduction programs, ARIS-II.

Operation of gamma, $\mathrm{X}$-ray detection systems is being hindered by insufficient multichannel analyzers (MCA), and electronic problems with existing MCA's.

Interface problems between an electronic data terminal and the NOVA 1220 computer have reduced data reduction capabilities 50 percent.

\section{Field Instrument Development - I. E. Bruns}

The objectives of this activity are to develop and demonstrate environmental instrumentation that will allow (1) in situ assaying of surface and subsurface radionuclides, (2) in situ measurement of radioactive toxic substance movement with time, and (3) improved efficiency and safety of environmental control. This instrumentation will provide capability to identify toxic substances loacted throughout the 200 Areas, their concentrations, and their movement toward man with time.

The following areas of work have been completed or initiated in support of this activity:

- Directional neutron counter for assaying surfaces.

- A maximum permissible concentration (MPC) water meter.

- Defining, developing, and procuring detectors and instrumentation for Dev-Van-I and Dev-Van-II.

- Developing and utilizing a special zinc sulphide alpha Eilter cloth monitor.

- Devising a special automatic system for controlling the measurement of wind speed and direction on resuspension towers. 
- Developing with Battelle-Pacific Northwest Laboratories temporary in-well radionuclide assay instruments [e.g." Ge(Li) small and large crystal detector systems, special windowed NaI(TI) detectors, and neutron detectors] and utilizing them for characterization.

- Assistance to operations in assessing subsurface leaks and measuring efficiency of immobilization techniques.

- Low-level argon dosimeter.

- Gamma aerial survey by helicopter.

Prints were completed on the calibration facility and two of the three systems have been approved. The facility will be located near the Redox Building and will consist of two submerged $4 I$ tanks $1.2 \mathrm{~m}$ in diameter and a $3.0-\mathrm{m}$ diameter tank containing four different matrices and a number of dry wells for detectors and sources. The calibration facility, planned for completion in June, was delayed by the HAMTC strike. Initiation of this work ( $J$. A. Jones Construction Company) will be strongly influenced by Hanford site priorities once the strike is settled.

A test was completed with National Nuclear Corporation and Hughes Research at Hanford concerning use of a cate detector for in situ plutonium and americium surface assaying. Without cooling, the cate crystal showed no improvement over the NaI(TI) crystal; and with cooling the intrinsic germanium and silicon detectors appeared to be superior.

Final problems concerning construction of the beta assayer were resolved and Battelle-Northwest was requested to build a mobile field unit. This unit is planned for completion by November 1976. 
Further experimental work was performed with copper foils to determine plutonium in gamma fields. Natural copper is activated to $64 \mathrm{Cu}$ and the decay gammas measured using a low-level detector system. Plutonium values were determined in the 8 to $30 \mathrm{nCi} / \mathrm{g}$ sediment range in moderate-to-high gamma level fields ( $100 \mathrm{mR}$ to $10 \mathrm{R}$ ).

\section{ANALYTICAL METHODS DEVELOPMENT}

Analytical Development for Waste Management - S. J. Johnson

\section{Gas Liquid Chromatography}

Laboratory work was completed on the determination of dibutylbutylphosphonate (DBBP) in the presence of tributylphosphate (TBP). A document (ARH-SA-249) has been written on this work and issued.

Gas chromatographic methods were developed for the analysis of Amberlite LA-2 (Rohm and Haas Company) and dihexy I-N-N-diethylcarbamy lmethylenephosphonate (DHDECMP) in support of solvent extraction work.

A method was also developed to determine the solubility of crown ethers in water and synthetic waste solutions. The concentration of the crown ether in the aqueous phase was less than 0.007 M. Further work will be done to obtain an actual value.

Procurement of a new automated gas chromatograph was approved. Specifications and a Procurement Request were submitted.

\section{High-Performance Liquid Chromatography}

Iiquid chromatograph equipment from seven companies has been evaluated for purchase. samples of DHDECMP in four stages of purification were submitted to a number of application laboratories. The results show liquid chromatographs to be a promising means of analyzing complex organic solutions. 
Actinide Analytical Program - S. I. Johnson

Fast and reliable analytical methods are being developed for concentrating and determining tracemaunts of actinides in various Hanford nuclear wastes. A solvent extraction method has been developed using $\mathbb{R} 1$ iquat-336 (General Mills, Inc.) and dibuty $1-\mathbb{N}-\mathbb{N}$-diethylcarbamylmethylenephosphonate (DBDECMP) which selectively isolates americium, curium, neptunium, plutonium, thorium, and uranium. Final methods of analyses of these isolated actinides are now being developed or improved.

\section{Electrodeposition}

An electrodeposition system has been set up to produce cleaner, more usable mounts for alpha energy analyses of americium, curium, neptunium, and plutonium. Two cells of a four-cell system have been installed and are in use. A series of " ${ }^{39} \mathrm{Pu}$ mounts ranging from 24 to $1.5 \mathrm{x} 10^{5}$ disintegrations/minute $(\mathrm{d} / \mathrm{m})$ and ${ }^{24}{ }^{3}$ Am mounts ranging from 29 to $1.1 \times 10^{5} \mathrm{~d} / \mathrm{m}$ were electroplated from an oxalate-chloride electrolyte. The plutonium recoveries ranged from 70 to 90 percent with most being $v 80$ percent. The americium recoveries fluctuated much more dramatically from 50 to 90 percent with most mounts being 070 percent. The discrepancies in recoveries are partially due to bad electrical connections caused by chlorine gas corrosion. Concentration of the actinides did not appear to affect recoveries. Contamination from the cells was detectable on mounts less than $100 \mathrm{~d} / \mathrm{m}$. cleaning the equipment in an ultrasonic bath relieved this problem. 
Thorium

Thorium is quantitatively isolated in $10 \mathrm{M} \mathrm{HCl}$ from Aliquat-336. A spectrophotometric method is being developed to determine thorium as an arsenazo-III complex. Two methods are being evaluated to overcome the interferences present in the $\mathrm{HCl}$ phase. A 12-run experiment using a Plackett-Burnam statistical design was used to determine which of six variables most affected complex formation in these methods. When using a boil-down prior to color formation, recovery was 100 percent with some decrease caused by the presence of HNO In the second method thorium is extracted into di(2-ethylhexyl)phosphoric acid (HDEHP) and the thorium - arsenazo-III complex formed in the organic phase. The Plackett-Burnam design showed $\mathrm{HNO}_{3}$ and the arsenazo-III matrix to have a significant effect on recovery. Good color stability was achieved in both methods.

\section{Analysis of Waste Tank Samples}

Six filtered waste tank samples were analyzed using electrodeposition to prepare mounts for alpha energy analysis (AEA) for $238,239 \mathrm{Pu},{ }^{241} \mathrm{Am},{ }^{243} \mathrm{Cm}$, and ${ }^{237} \mathrm{~Np}$. P1utonium-236 and $24{ }^{3} \mathrm{Am}$ were used as tracers. Excellent AEA's were achieved and, although the spike recoveries ranged from 40 to 95 percent, the collected values correlated well with past data. Duplicate samples were in agreement. The lower recoveries appear to be caused by lanthanide interferences. PIutonium recovery was increased by 20 percent when a bisulfate melt was made prior to electroplating. Neptunium-237 values were also obtained, but could not be corrected since a tracer had not been added. 
Three of these samples were also analyzed for total thorium. The thorium - arsenazo-III comples was developed by both the boil-down and HDEHP methods. The results from the preliminary analyses were:

$\begin{array}{ll}109-\mathrm{BX} & 0.74 \mu \mathrm{g} / \mathrm{ml} \text { sample } \\ 109-\mathrm{TX} & 0.50 \mu \mathrm{g} / \mathrm{ml} \text { sample } \\ 110-\mathrm{BX} & 0.20 \mu \mathrm{g} / \mathrm{ml} \text { sample }\end{array}$


ENVIRONMENTAL CONTROL TECHNOLOGY

MANAGEMENT OF SURPLUS FACILITIES AND EQUIPMENT

\section{DISPOSITION METHODS RESEARCH AND DEVELOPMENT}

Contaminated Equipment Volume Reduction - D. C. Nelson, Program Manager

The objective of this activity is to develop and demonstrate methods for reducing the volume of radioactively contaminated metalic items to a size and form suitable for interim or final storage. Although the problem of disposition of contaminated equipment exists throughout the nuclear industry, this activity is focusing its attention on the contaminated, decommissioned equipment presently located in the chemical processing areas at Hanford. Cold testing of size-reduction and volume-reduction equipment will begin by the end of FY 1978. Hot testing of size-reduction equipment will begin in FY 1981, and hot tests with volumereduction equipment will begin in FY 1982.

Decontamination Evaluation - G. A. Beitel

The purpose of this activity is to evaluate costs and secondary waste generation associated with equipment decontamination as a precursor to volume reduction. A decontamination test on a Purex dissolver has been planned to provide this information.

Several cleaning cycles were carried out during April after which it was discovered that the major contamination was trapped between the tank wall and an outer heat insulation jacket. Removal of the jacket had just been initiated when the HAMTC strike began. There is an estimated two to three weeks work remaining on this task and it is planned to be completed after the 


\section{Size Reduction Evaluation - G. A. Beitel}

This activity attempts to devise a system which can demonstrate that large, multi-ton stainless steel process vessels can be safely, rapidy, and remotely cut into small pieces that will be easier to handle and melt down.

Following the successful arc saw test at ReTech, Inc. (formerly Schlienger, Inc.) of San Rafael, California, during the previous report period, the acquisition of an arc saw specially designed for demolition work was initiated. A prototype approval letter for the purchase of an arc saw was written and forwarded to ERDA-RL. Further action awaits ERDA response.

The major effort of this activity has been the design of a size-reduction test stand. A versatile stand, capable of handing a 10-foot-diameter, 10-foot-high vessel under water is being designed. It will provide a turntable for the workpiece that can be raised or lowered during cutting operations. It will permit the testing of various cutting devices. Water and air purification systems will prevent the spread of contamination and allow visual observation. A preliminary version has been drafted and is presently under review.

Further effort was expended to evaluate shut-down chemical processing buildings as possible locations for the experimental activities and apparatus supporting the Contaminated Equipment Volume Reduction activity. The remote shop and decontamination cell of the Redox canyon building are the principal candidates under consideration; they offer a good supply of space, utilities, and available manpower. 


\section{Volume Reduction Evaluation - G. A. Beitel}

This activity attempts to determine whether radioactively contaminated equipment can be safely melted and cast as a product acceptable for final storage. The specific objective is the design of a low-maintenance, remotely operated meltdown system incorporating maximum fume control. In support of this work, experimental meltaown of contaminated stainless steel pipe samples has yielded promising decontamination results.

A contract was negotiated with ReTech. Inc., for the detailed design of a cold-wall vacuum furnace of sufficient size to melt 1,000-pound individual batches of stainless steel scrap. The contract began in the last week of May and will be completed by october 1, 1976. The basic system parameters were identified and a preliminary sketch of the furnace chamber was drawn. The furnace is being designed for remote operability and maximum fume control; however, several years of operation with nomradioactive material are planned, the results of which will provide the basis for any decision to operate this model with contaminated material. 
REFERENCES

1. ARH-ST-132 C, June 1976, J. S. Kounts, ed., "Atlantic Richfield Hanford Company quarterly Report, Technology Development for Long-Term Management of Hanford High-Level Waste, January 1976 through March 1976."

2. DPST-74-125-3, "Savannah River Laboratory Quarterly Report, Waste Management, JulySeptember $1974 . "$ 
DISTRIBUTION

Energy Research and Development Administration

Richland Operations office

T. A. Bauman

O. J. Bennett

P. A. Craig

O. J. Elgert (3)

R. B. Goranson

P. G. Holsted

J. L. Rhoades

P. G. Rhoades

\section{Albuquerque Operations office}

D. Davis, Ir.

Headquarters

F. P. Baranowski

M. B. Biles

G. M. Daly

O. P. Gormley

H. Hollister

C. W. Kuhlman

A. Perge

G. B. Pleat

R. W. Ramsey, Jr.

D. E. Saire

Idaho Operations office

G. Wehmann

Oak Ridge Operations Office

V. J. D'Amico

E. H. Hardison

J. J. Schreiber

Savannah River Operations office

R. L. Chandier
N. Stetson

Technical Information Center 
DISTRIBUTION (continued)

\section{Allied Chemical Corporation}

C. M. Slansky

Argonne National Laboratory

M. J. Steindler

\section{Battelle Pacific Northwest Laboratories}

N. E. Carter

D. B. Cearlock

G. W. Dawson

R. L. Dilion

J. R. Eliason

J. W. Finnigan

E. R. Irish

J. H. Jarrett

H. V. Larson

R. P. Marsha 11

J. L. MCEIroy

J. M. Nielson

R. E. Nightingale

D. E. Oleson

I. T. Pederson

A. M. Platt (2)

W. H. Rickard/R. E. Wildung

I. C. Schwendiman (2)

C. L. Simpson

C. M. Unruh

H. H. Van Tuy 1

B. E. Vaughan/R. F. Foster

E. I. du Pont de Nemours and Company

Savannah River Laboratory

J. A. Crandall

G. G. Goodlett

H. T. Groh/A. S. Jennings

C. H. Ice

B. C. Rusche/D. A. Orth 
Savannah River Plant

E. O. Kiger

S. Mirshak

W. J. MotteII

Wilmington, Delaware

R. E. Naylor

J. F. Procter

Holifield National Laboratory

J. O. Blomeke

Los Alamos Scientific Laboratory

F. A. Guevara

Union Carbide Corporation, Nuclear Division, Office of Waste Isolation, Oak Ridge

W. C. MCClain

C. D. Zerby

United Nuclear Industries

A. P. Larrick

Atlantic Richfield Hanford Company
M. D. Alford
N. M. Arnold
H. Babad/D. C. Lini
G. S. Barney/M. R. Fox
D. C. Bartholomew
M. M. Beary/P. C. ElY
G. A. Beitel
C. R. Bergdahl
D. E. Braden
L. E. Bruns/R. D. Fox
J. S. Buckingham/J. E. Horton
G. Burton, Jr.
D. D. Chen/S. A. Gott
I. A. Chick
R. A. Deju
D. A. Dodd/S. J. Johnson 
DISTRIBUTION (continued)

Atlantic Richfield Hanford Company (continued)

J. Faulhaber

R. E. Felt

R. G. Geier

R. B. Gelman

D. R. Gustavson

G. L. Hanson

D. G. Harlow

W. M. Harty, Jr.

O. F. Hill

H. H. Hopkins, Jr.

I. C. Hubbard

W. P. Ingalls

J. D. Kaser

D. E. Kelley

I. M. Knights

E. J. Kosiancic

J. S. Kounts

M. J. Kupfer

M. W. Legatski/D. J. Brown

R. Y. Lyon

C. W. Malody/G. W. Cramer

C. W. Manry

P. F. Mercier

D. C. Nelson

G. A. Nicholson

R. G. Oliver

J. I. Peterson

I. E. Reep

R. C. Roa1/W. Watson, Jr.

W. L. Schick

W. W. Schulz/C. W. Hobbick

H. P. Shaw

A. E. Smith

C. P. Sutter

R. J. Thompson

H. A. Wallskog

J. H. Warren

R. A. Watrous

D. D. Wodrich

R. A. Yoder

W. H. Zimmer

ARHCO Document Services (3) 